\author{
J ULIA L Y N N CORONADO
}

Board of Governors of the Federal Reserve System

STEVEN A. SHARPE

Board of Governors of the Federal Reserve System

\title{
Did Pension Plan Accounting Contribute to a Stock Market Bubble?
}

DURING THE 1990S THE assets of corporate defined-benefit (DB) pension plans ballooned as a result of the booming stock market. Because of accounting rules for DB plans put in place in 1986, this robust growth provided a substantial, although stealthy, boost to the profits reported by sponsoring corporations. In particular, the extraordinary returns earned on pension assets flowed to the bottom line on corporate income statements through lower net pension cost accruals included in general corporate expenses.

These developments may have misled many investors about the value of corporate equities, because pension cost accruals provide a fairly convoluted signal of the underlying value of net pension assets, in two ways. First, the accounting rules allow firms to smooth the effect of volatility in asset returns in calculating net pension expense; this smoothing both hides the variation inherent in the realizations of risky returns and tends to make current accruals of pension cost a stale measure of a pension plan's net asset value. Second, the net costs of financing outstanding pension liabilities are effectively understated when pension sponsors assume a future rate of return on plan assets that far exceeds the discount rate they use to calculate the present value of plan obligations. In effect, the costs associated with providing a pension plan to employees are offset

The views expressed in this paper are the authors' and do not necessarily reflect the views of the Board or the staff of the Federal Reserve System. We thank Gene Amromin, Jason Cummins, Jeremy Gold, Stephen Oliner, and Mark Warshawsky for comments and suggestions, and Eric Richards and Carter Copeland for excellent research assistance. 
on the sponsoring firm's financial statements by a smoothed and inflated stream of income flowing from the pension portfolio.

In this paper we assess the degree to which investors may have been fooled by current pension accounting rules and practices. We do so using two alternative models of pension valuation. The first, known as the standard transparent model, holds that investors gauge the contribution of a pension plan to the sponsoring firm's value by looking at the plan's marked-to-market net asset value, which is reported in footnotes to the firm's financial statements. The second, the "opaque" model proposed by Jeremy Gold, presumes that the market's assessment of net pension value is driven instead by the pension cost accruals reported in the body of the firm's income statement. ${ }^{1}$

Our analysis applies a standard framework for equity valuation based on abnormal earnings and shows that, under the current accounting regime, the market appears to pay more attention to the flow of pensioninduced accruals reported in the body of the income statement than to the marked-to-market value of pension assets and liabilities reported in the footnotes. These findings strongly support the predictions of the opaque model of pension valuation. We then perform a second battery of tests to determine whether the market prices a firm's pension accruals any differently than it prices the firm's core business earnings. The results suggest that investors do not distinguish between these two sources of earnings, at least not in the way that one would expect in an efficient market. If anything, the earnings associated with pension accruals appear to receive a higher valuation multiple than do core earnings.

Finally, we bring this evidence to bear on the question of whether there was a substantial pension-induced bubble in equity prices by simulating firm-level valuation errors using one of the empirical models employed in our hypothesis tests. The simulations suggest that, for the average firm in the Standard \& Poor's (S\&P) 500 with a DB plan, pension-induced valuation errors added 2 to 3 percent to the stock price during the late 1990s. Although significant in terms of absolute dollars of wealth, this source of error thus explains little of the runup in stock prices over this period. However, the estimated pension-induced distortions rise considerably in 2001, when the plunge in pension net asset values had not yet shown through to pension cost accruals. In particular, we estimate that, as of

1. Gold (2000). 
early 2002, one-tenth of the firms in our sample that sponsored a DB pension plan were at least 20 percent overvalued, relative to otherwise similar firms, and that the unweighted average level of overvaluation of the stocks of pension-sponsoring firms was 10 percent. When gauged on a market capitalization-weighted basis, the simulated valuation distortions of firms in the S\&P 500 that sponsor pension plans are about half that size.

\section{Background and Previous Research}

Employer-provided pensions were first introduced as a form of deferred compensation in the late nineteenth century. Defined-benefit pensions became more popular as the work force industrialized and life expectancies extended beyond the maximum age at which workers could be productive in an industrial setting. (A defined-benefit pension is one in which benefits are known in advance and based on the retiring worker's past salary and years of service, rather than on the amount of past contributions on the worker's behalf plus returns.) Pensions seemed an effective way for employers to reduce employee turnover and regulate retirement patterns, as well as to encourage productivity, thereby contributing to firm value. ${ }^{2}$ These plans became increasingly widespread after Congress, beginning in the early 1940s, made employer contributions taxexempt and allowed deferral of taxation on investment earnings accrued within the plan.

Although the last twenty years have seen a trend away from DB plans toward defined-contribution plans, more than two-thirds of firms in the S\&P 500 currently sponsor a DB pension plan, and the assets these plans manage have averaged around 15 percent of the market value of the sponsoring firm. Indeed, as figure 1 shows, the fair market value of assets held by the DB plans of S\&P 500 firms nearly doubled during the second half of the 1990s, to a peak of just under \$1.2 trillion in 1999.

Private, employer-sponsored DB plans are currently regulated under the Employee Retirement Income Security Act (ERISA) of 1974, which

2. For a more complete discussion of the evolution of private pension funds and their role in the labor market, see Gustman, Mitchell, and Steinmeier (1994) and McGill and others (1996). 
Figure 1. Pension Assets and Obligations of S\&P 500 Firms, 1993-2001 ${ }^{\mathrm{a}}$

Trillions of dollars

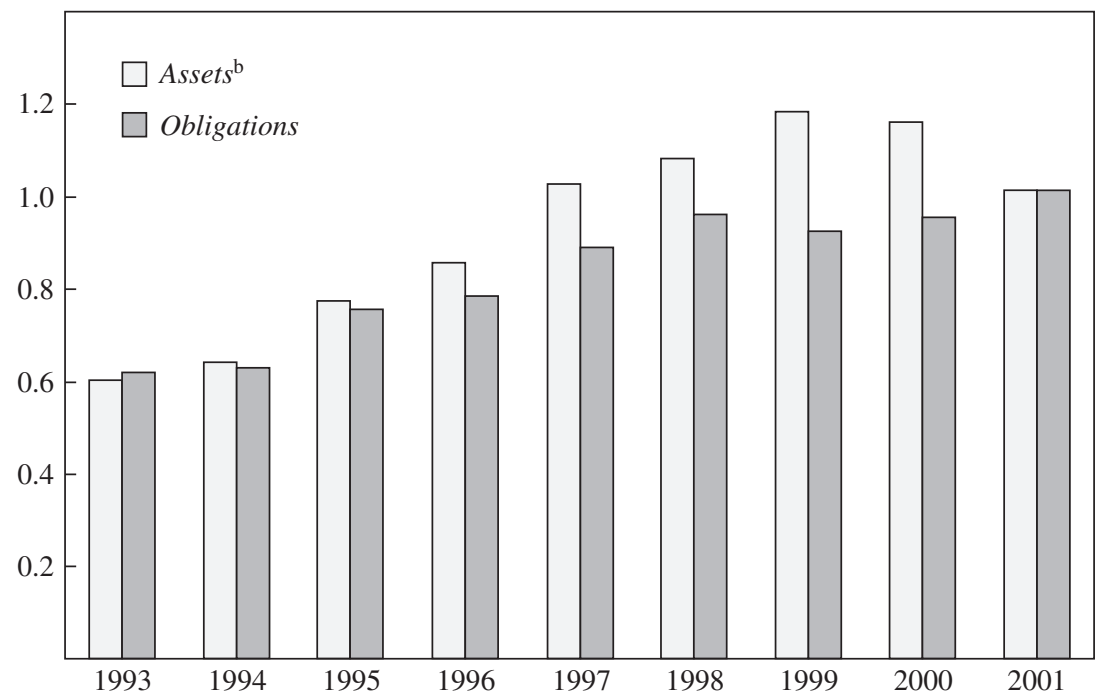

Source: Compustat and I/B/E/S.

a. Firms with defined-benefit (DB) pension plans only (on average 375 firms each year). Includes back data on firms added to composite from 1997 to 1999.

b. At fair market value.

requires, among other things, that firms prefund benefits (rather than plan on paying them out of future operating profits) and invest plan assets prudently. Under ERISA rules, if the ratio of the current market value of a plan's assets to the current value of its liabilities — the funding ratio-falls to between 80 and 90 percent, the firm must under some circumstances accelerate its cash contributions to the plan. If the funding ratio falls below 80 percent, accelerated cash contributions are unconditionally required. In calculating the present value of liabilities so as to determine the funding ratio, firms must use a discount rate linked to the thirty-year U.S. Treasury bond. ${ }^{3}$ Because plan participants have a legal claim under

3. More recently, yields on the thirty-year Treasury bond have been driven down by more than the general decline in long-term rates would dictate, because of the shrinking supply of this instrument. The consequent decline in discount rates has exacerbated funding problems for plans whose asset values had already plunged. Pension funds were granted a temporary reprieve in the form of a two-year period during which they are allowed a greater deviation from the average thirty-year Treasury bond yield in determining the 
ERISA regulations to their accrued benefits, the firm's shareholders are effectively the residual claimants on any excess or shortfall of funds relative to that claim.

\section{Implications for Sponsoring-Firm Value}

How assets in a DB pension plan should affect the value shareholders place on the sponsoring firm's equity is most easily understood in a simple benchmark model with no taxes and no government regulation of pensions. In this model the marked-to-market values of pension assets and liabilities are transparent to investors and contribute to firm value dollar for dollar. This model is often referred to as the consolidated balance sheet approach, because the assets and liabilities of the pension plan are viewed no differently from other financial assets and liabilities of the firm. Here we refer to it as the transparent model, to contrast this view of pension valuation with the alternative, opaque model, in which the value of the pension plan is not well understood by investors.

Two modifications are typically made to the benchmark transparent model. The first arises from the tax preferences afforded to pension plans. Because plan contributions are tax deductible, each dollar of liability incurred and funded through such contributions reduces the equity value of the firm by only $(1-T)$, where $T$ is the combined federal and state marginal tax rate. Likewise each dollar of assets in the pension fund should be valued at its replacement cost, again $(1-T)$. Several authors have shown that, beyond the deductibility of contributions, the nontaxability of returns on pension fund assets has further implications for optimal funding strategies and net pension valuation. ${ }^{4}$ Firms can minimize the present-value cost of future pension liabilities by maximizing current tax-deductible contributions. In addition, Martin Feldstein and Stephanie Seligman showed that the tax deductibility of contributions and the tax exemption of returns on pension assets interact with the term structure of liabilities and the funding schedule of the sponsoring firm in determining the marginal contribution of net pension liabilities to firm value. Given these considerations, the marginal effect of a dollar of net pension assets is nonetheless bracketed by $(1-T)$ and 1 .

discount rate they use for funding calculations, while Congress reviews the issue of discount rates.

4. Black (1980); Feldstein and Seligman (1981); Tepper (1981). 
A further modification to the simple transparent model arises from the insurance that pension funds purchase from the government-run Pension Benefit Guaranty Corporation (PBGC). ${ }^{5}$ The PBGC covers any shortfall in funding for pension plans of bankrupt firms, in effect providing a put option that trims some of the negative impact of pension liabilities on firm value. This insurance has the effect of reducing the cost to shareholders of the marginal dollar of pension liabilities, although this caveat is more important for unprofitable firms facing a substantial risk of failure.

The transparent model, modified by the tax and insurance considerations just discussed, has been the dominant valuation model for firms with DB pension plans in empirical research to date. In the late 1970s the increased prevalence of underfunded pension plans spurred a group of empirical studies aimed at estimating the impact of DB pension plans on firm valuation. ${ }^{6}$ A chief concern was that DB pension plans would justifiably reduce saving by plan participants; if, however, share prices then did not properly reflect the extent of underfunding, stockholders would fail to increase their saving accordingly, producing a net reduction in national saving. These studies modeled the total market value of the firm as proportional to the replacement value of its underlying assets and included unfunded pension liabilities as an explanatory variable. These studies generally concluded that the market valued net pension liabilities in a manner consistent with the transparent model.

Despite these findings, many market participants at the time suspected that share prices did not adequately reflect the mostly unfavorable financial position of DB pension plans. In particular, the financial community worried that plan assets and liabilities were measured inconsistently across firms and were not adequately disclosed, making it difficult for investors to accurately determine the impact of DB pensions on firm value. Although firms were required to disclose their net pension assets, they were not required to do so within their financial statements. ${ }^{7}$ Indeed, the only manifestation of DB plans in these statements was the cash con-

5. This result was first established by Sharpe (1976).

6. These papers include Feldstein and Seligman (1981), Feldstein and Mørck (1983), and Bulow, Mørck, and Summers (1987). Munnell and Ernsberger (1987) also explored the relationship among the stock market, pension funding, and saving. Mittelstaedt and Warshawsky (1993), among others, employed a similar framework to examine the impact on firm value of liabilities associated with retiree health benefits.

7. See McGill and others (1996) for a more complete description of the evolution of pension accounting. 
tribution to the plan, which flowed through as an expense on the income statement. Furthermore, companies used a variety of actuarial methods and assumptions to determine the market value of plan liabilities.

To address these concerns, the Financial Accounting Standards Board (FASB) issued Statement No. 87, Employers' Accounting for Pensions, which stipulated a new accounting approach to be employed in fiscal years beginning after December 15, 1986. ${ }^{8}$ Broadly speaking, FAS 87 standardized the actuarial assumptions to be used in valuing pension liabilities and set forth a new method of accounting for pension expense on the income statement. Rather than book actual cash contributions, companies would calculate pension expense using a complicated accrual methodology. The guidelines also required disclosure of the fair market value of pension assets and liabilities within the footnotes to the annual financial statements. ${ }^{9}$

\section{Pension Accounting after FAS 87}

Under the guidelines established by FAS 87, the measure of pension expense reflected in the income statement, called the net periodic pension cost (NPPC), is calculated as the annual accrued costs of the pension plan minus the expected return on plan assets. As shown in table 1, the primary cost components of the NPPC are service cost and interest cost. "Other costs" includes amortization of previous gains and losses as well as ad hoc items such as one-time charges for plan amendments or changes in actuarial assumptions.

Service cost is equal to the present value of the pension benefits earned by employees during the year; in essence, it is the cost of deferred compensation. Interest cost is calculated as the beginning-of-year value of pension obligations multiplied by the plan's assumed discount rate; this represents the cost of financing the outstanding pension obligation, that is, the increase in the benefit obligation resulting from the passage of time. Under FAS 87 guidelines, the assumed discount rate must reflect the rate at which current liabilities could be settled. As a matter of practice, firms

8. Financial Accounting Standards Board (1985).

9. Although many of the general principles for setting the actuarial assumptions used in the accounting calculations are similar in spirit to those used in the funding calculations required under ERISA, they are not explicitly linked. 
Table 1. Accounting Concepts for Defined-Benefit Pension Plans

\begin{tabular}{ll}
\hline Accounting concept & \multicolumn{1}{c}{ Definition } \\
\hline $\begin{array}{l}\text { Service cost } \\
+ \text { Interest cost }\end{array}$ & $\begin{array}{c}\text { Present value of benefits earned in the current year } \\
\text { Cost of financing the outstanding benefit obligation }\end{array}$ \\
+ Other costs & $\begin{array}{c}\text { Includes costs of plan amendments and changes in } \\
\text { actuarial assumptions }\end{array}$ \\
- Expected return on plan assets & Assumed return on market-related value \\
$=\begin{array}{c}\text { Net periodic pension cost } \\
(\text { NPPC })^{\mathrm{a}}\end{array}$ & \\
$-\begin{array}{l}\text { Service cost } \\
=\text { Pension earnings }\end{array}$ & As defined above \\
\hline
\end{tabular}

Source: Financial Accounting Standards Board (1985).

a. This item is included as a cost on the firm's income statement.

often use the average yield to maturity on bonds with a Moody's AA credit rating. ${ }^{10}$ The offset to plan costs in the NPPC is the expected return on plan assets, which is calculated as the product of two items: the assumed long-run rate of return on plan assets, and the accounting value, or "market-related value," of those assets. The market-related value can be either the current fair market value of assets or a systematically smoothed accounting value, whereby unexpected returns are amortized over a period not exceeding five years. Thus, for firms that choose the maximum amortization period, ${ }^{11}$ the market-related value would be similar to a five-year moving average of the true market value. Consequently, the expected-return component of the NPPC will in many cases reflect the actual market value of pension assets only with a substantial lag.

The key assumption used in calculating the expected-return component is the long-run rate of return on plan assets, which is generally different from the discount rate used to calculate the present value of liabilities and the current year's interest cost. Under the FAS 87 guidelines, in choosing this assumption the firm must consider the return currently being earned on plan assets and rates of return expected in the future, but it need not consider the variance in that expected return. Thus, for accounting pur-

10. Historically, the discount rate used for calculations in the financial statements has been reasonably close to that used for funding calculations.

11. This is the majority of firms according to Zion and Carcache (2002). 
poses, the firm is explicitly directed to use an expected rate of return without regard to the riskiness of the underlying portfolio. ${ }^{12}$

Given that the volatility of actual returns on pension plan assets is not disclosed to investors, and that the assumption for the expected return on the plan's portfolio is not adjusted for risk, Gold argues that FAS 87 formalizes a systemic financial bias in pension accounting that favors equity investments. ${ }^{13}$ In choosing the plan's expected long-run rate of return on pension assets, firms anticipate, or assume, an equity premium. At the same time, because of the smoothing built into the NPPC from using expected returns with amortization, little of the volatility that gives rise to the equity premium shows up on the sponsoring firm's financial statements. Rather, the underlying income volatility (as well as the effective boost to leverage) is revealed only through the disclosure of marked-tomarket values for pension assets and obligations in the footnotes to the financial statements.

Gold thus suggests that the standard transparent model of pension valuation used in earlier academic analyses likely does not hold. He hypothesizes instead an opaque model of pension valuation, whereby investors value the stream of pension expense reported on the income statement, rather than the marked-to-market value of net pension assets as implied by the transparent model. Because the information presented on the income statement understates the true risk-adjusted pension expense, the opaque model implies that the market is prone to overprice firms that sponsor DB pension plans. ${ }^{14}$

12. Most of our sample period is characterized by long-term interest rates that were low relative to firms' assumed long-run equity returns. Indeed, the average assumed long-run rate of return in our sample was around 9 percent, whereas the average discount rate was closer to 7 percent.

13. Gold (2000).

14. The discrepancy between the assumed rate of return and the discount rate generates a flow of income from pension plan operations on the income statement of the sponsoring firm. To see this, consider a plan that starts the period fully funded, that is, where the value of assets exactly equals the value of liabilities. The expected return on plan assets, calculated by multiplying the value of plan assets by the assumed rate of return, will more than offset the interest cost, calculated as the product of the discount rate and the plan's liabilities. This excess of expected asset growth over liability growth will partly cover the cost of benefits earned by employees in the current period (the service cost), and will do so in perpetuity. Thus it would appear that the labor costs include a benefit that the firm does not have to fund completely. 
In support of this view, Gold points out that the behavior of corporate managers is clearly at odds with the model of the pension plan as a transparent financial subsidiary. First, corporate managers show a strong preference for smoothing at the expense of transparency, a preference evidenced by the heavy lobbying that produced the compromises in the FAS 87 guidelines. Second, the high proportion of equity investments in pension plans has persisted for decades, despite tax and other considerations that arguably favor debt. ${ }^{15}$

The opaque model of pension valuation as laid out by Gold is theoretical, with little previous empirical evidence to support or refute it. One exception is an analysis by Mary Barth, William Beaver, and Wayne Landsman, who tested whether the market values the various components of net pension expense differently from each other and from other components of earnings. In ancillary regressions they also examined the relative importance of pension balance sheet information and found that, when pension assets and liabilities are included, the various individual components of NPPC are mostly insignificant. ${ }^{16}$ Although their results provide some support for the transparent view of pension valuation, they are based on data from 1987-90, the initial years under the new accounting regime, perhaps before valuations fully reflected the new information. More recently, Stephen Brown examined whether investors "discount" any of the assumptions underlying the calculations of pension liabilities and concluded that the market penalizes firms whose assumptions lie outside an economically justifiable range. ${ }^{17}$ This result suggests a high degree of efficiency in market pricing; however, we will argue that, because information on pension cost accruals is omitted, such results could be spurious.

In recent years the potential for conflicting signals from the accruals on the income statement and the marked-to-market pension balance sheet has

15. The transparent model with taxes also implies predictions for asset allocation within the pension plan. Black (1980) and Tepper (1981) assert that the tax-free accrual of pension investment returns gives firms the incentive to hold the most highly taxed instruments inside the pension fund, which would imply that pension funds should be invested 100 percent in taxable fixed-income securities. Weighing against this incentive, the tax deductibility of contributions also provides insurance against investment losses, resulting in an incentive for taking risks with pension fund assets that potentially explains the high degree of equity holding by DB pension funds (Bulow, Mørck, and Summers, 1987).

16. Barth, Beaver, and Landsman $(1992,1993)$.

17. Brown (2002). 
been exacerbated by the stock market's boom and bust. As a result, practitioners in the financial accounting community have voiced increasing dissatisfaction with the accounting framework. One notable recent development is S\&P's introduction of "core earnings," in an attempt to create a standard non-GAAP alternative for gauging operating earnings. (GAAP is an acronym for Generally Accepted Accounting Principles.) One key departure from standard practice is S\&P's treatment of pension expense in core earnings, which excludes the expected-return component.

Several major Wall Street firms and prominent investment gurus such as Warren Buffett have called for a more fundamental measure of pension costs. For instance, Jack Ciesielski, and David Zion and Bill Carcache, argue that service cost-the component of pension cost that represents accrual of benefits-is the only component that should be included in net operating income. ${ }^{18}$ Harris and others suggest that FASB is likely to propose changes to pension accounting standards similar to recent amendments in U.K. standards, which reduced the smoothing in calculations of pension costs and separated the compensation and financing components. ${ }^{19}$ Indeed, FASB recently announced a project to review standards for pension accounting, with the goal of issuing a revised standard in 2004. Thus the controversy that has erupted over the last few years indicates that many practitioners believe net pension values are not transparent to investors. The empirical analysis that follows explicitly tests whether such concerns are valid.

\section{Empirical Model}

To simultaneously gauge the influence of pension assets and earnings on equity valuations, we employ the empirical valuation model advanced by Gerald Feltham and James Ohlson, which is a parsimonious application of the residual income model. ${ }^{20}$ In the residual income model, a firm's market equity value is equal to its book equity value plus the present discounted value of its expected abnormal earnings; in per-share terms,

18. Ciesielski (2002); Zion and Carcache (2002).

19. Harris and others (2002).

20. Feltham and Ohlson (1995). 


$$
P_{t}=\mathrm{BV}_{t-1}+\sum_{i=1}^{\infty} \frac{x_{t+i}}{(1+r)^{t+i}}
$$

where $x_{t+i}=\mathrm{EPS}_{t+i}-r \mathrm{BV}_{t+i-1}$ is residual or abnormal earnings per share in period $t+i$. In words, abnormal earnings per share is net income (total earnings per share, or EPS) in excess of the firm's cost of equity capital, where the latter equals the firm's required rate of return times its equity book value per share (BV).

Under simplifying assumptions about the dynamics of abnormal earnings, this model can be reduced to the following equation:

$$
P_{t}=\alpha_{1} \mathrm{BV}_{t-1}+\alpha_{2} \mathrm{EPS}_{t}+u_{t},
$$

where the multipliers on EPS and BV are a function of the required rate of return and the dynamics of expected earnings and book value. For instance, the multiplier on current earnings is larger for firms with more highly autocorrelated or faster-growing earnings, holding constant the path for book value. ${ }^{21}$ In the simple case where the current level of earnings is expected to be permanent, $\alpha_{2}$ should equal $1 / r$, the inverse of the discount rate.

In implementing this model, we employ analyst forecasts of currentyear earnings rather than lagged actual earnings. We follow this tack because near-term analyst forecasts generally have much greater explanatory power for stock prices than do lagged earnings. ${ }^{22}$ Presumably the reason is that actual earnings include substantial temporary components that are idiosyncratic to the period at hand. Forecasts, in contrast, tend to abstract from idiosyncratic developments and thus should be more closely correlated with the perceived trend level of earnings.

Our adaptation of the residual value model also includes the twist introduced by Feltham and Ohlson, where firm value is expressed as the value emanating from the firm's nonfinancial operating activities plus the value of its financial activities. In particular, we divide both the balance sheet and the income statement of the firm into two parts: core operations

21. Under the usual assumed accounting system, for any given path for book value, together with a given path for earnings, there would be an associated implied path for dividends.

22. Indeed, in their empirical assessment of the residual income model, Dechow, Hutton, and Sloan (1999, p. 26) show that "analysts' forecasts of next year's earnings subsume value relevant information in [the most recent year's] earnings." 
and the financing operations related to outstanding pension plan liabilities. Core book equity value (BVC) is equal to total book equity value minus the book value of net pension assets (NPA), all per share. Earnings per share generated by core operations (core EPS) equals total EPS minus pension earnings per share (pension EPS), the latter being the accruals associated with the financing and management of outstanding pension obligations and assets. Note that we define pension EPS as NPPC per share minus the service cost component; that is, unlike the financing of outstanding pension obligations, the accrual of new pension obligations from current labor services is treated as a core expense. Thus, in accordance with the transparent view of pension valuation, the firm's share price can be expressed as

$$
P_{t}=b_{1} \mathrm{BVC}_{t}+b_{2} \text { core } \mathrm{EPS}_{t}+b_{3} \mathrm{NPA}_{t}+u_{t},
$$

where NPA is calculated as the fair market value, per share, of pension assets less the present value of accrued liabilities, and pension EPS is not included because it is arguably redundant to the pension balance sheet measure.

The first hypothesis tested, using equation 3, is whether a firm's stock price reflects the fair market value of pension assets and liabilities published in its most recent annual 10-K report, in a manner consistent with the transparent model of pension valuation. Again, theory predicts that the coefficient on NPA should fall between 1 and $(1-T)$, where $T$ is the effective marginal tax rate faced by the firm, although the coefficient might also be influenced by other factors such as the funding status and the timing of contributions relative to the rate at which liabilities are accrued.

We then test the transparent model against the opaque model by adding current-period pension earnings to the regression equation. In theory, this variable should not contribute to firm value, since the capitalized value of current and expected future earnings (or costs) from outstanding net pension assets (or obligations) should already be reflected in the value of net pension assets. Thus we estimate

$$
P_{t}=b_{1} \mathrm{BVC}_{t}+b_{2} \text { core } \mathrm{EPS}_{t}+b_{3} \mathrm{NPA}_{t}+b_{4} \text { pension EPS }+b_{0}+u_{t} .
$$

In the transparent model, $0.65<b_{3}<1$, and $b_{4}=0$. In the opaque view of pension valuation, $b_{3}=0$ and $b_{4}>0$. 
If the econometric test favors the opaque model, the magnitude of $b_{4}$ will provide an indication of the extent to which the stocks of firms with DB pension plans are mispriced. Even if investors rely on accounting earnings to value the pension plan, they might do so in a manner consistent with the transparent model. This would be the case if the magnitude of $b_{4}$ were close to the ratio of NPA to pension EPS (or a bit less, assuming a positive effective tax rate on plan assets). Otherwise, investor focus on pension accruals would result in the firm's stock being mispriced. In the extreme, the market may fail to differentiate between pension earnings and core earnings altogether, a hypothesis examined by testing whether $b_{4}=b_{2}$. If investors do fail to differentiate between these two components of earnings, the pension earnings of at least some firmsparticularly those rapidly growing firms with high core price-earnings ratios—are probably being overvalued.

\section{Data, Variable Construction, and Sample Statistics}

The two principal sources of data for the analysis are Compustat and I/B/E/S International: the former for historical financial data, including items related to company DB pension plans, and the latter for stock prices and analyst earnings forecasts. To construct our sample, we begin with all firms that were in the S\&P 500 anytime from December 1996 through December 1999. A handful of firms are excluded because of incomplete or inscrutable data on their pension plans, but firms without DB pension plans are included. For this sample we extract annual financial data from Compustat for the period 1993-2001, including several variables related to the financial position of DB pension plans as well as book equity values and the number of shares on a fully diluted basis. We begin our analysis in 1993 because many pension variables are unavailable in Compustat before that year.

Compustat data are merged with data from the I/B/E/S monthly history files using firm CUSIP numbers. Items taken from I/B/E/S include annual observations on stock price, shares outstanding, actual operating earnings per share, consensus (mean) forecasts of earnings per share for the current fiscal year and for the following year, and the median analyst long-term growth forecast. The timing of the data match is chosen so that the company's stock price and analyst earnings forecasts are measured subse- 
quent to the release of the previous year's results, including the details in the firm's 10-K report. The annual Compustat data for firms with fiscal years ending in October through March (mostly December) are matched with the price and forecast data published by I/B/E/S the subsequent May; for firms with fiscal years ending April through September, annual financial data are matched to November I/B/E/S data.

After filtering out firms with incomplete data, we are left with over 4,400 observations, or an average of 490 firms a year. For most of the analysis we excluded the relatively few observations for which both current-year and subsequent-year earnings per share forecasts are negative, since the parsimonious dynamics presumed in our valuation model are poorly suited for firms for which trend earnings are negative. The final dataset thus contains 4,359 firm-year observations, 3,335 of them from firms with an active DB pension plan.

The key pension variables drawn from Compustat are defined as follows:

-Pension plan assets: the fair market value of plan assets

-Projected benefit obligation: the actuarial present value of benefits earned by employees to date, taking into account expected future salary increases $^{23}$

-Prepaid or accrued pension cost: the measure of net pension obligations recognized in firm book value

-Net periodic pension cost (NPPC): the annual expense booked for DB plans

- Service cost: the cost of benefits accrued during the year (a component of NPPC).

23. If employees leave the firm or the firm goes bankrupt, the more appropriate measure of liability is the accumulated benefit obligation (ABO), often referred to as the termination benefit. The projected benefit obligation (PBO) differs from the $\mathrm{ABO}$ in that it builds in an assumption of future salary increases for plan participants; it is therefore called the continuation liability - that is, the true cost of benefits earned to date that the firm expects to face if it remains in business. There is some debate as to whether the termination liability (the $\mathrm{ABO}$ ) or the continuation liability (the $\mathrm{PBO}$ ) is the appropriate measure of a firm's pension liability. For the vast majority of observations in our sample, the prospect of bankruptcy is remote, and thus the PBO would seem to be the more appropriate measure. But variations in the $\mathrm{ABO}$ and the $\mathrm{PBO}$ (over time or across firms) are likely to be quite similar, and therefore we do not believe our results would be fundamentally different if the $\mathrm{ABO}$ were used instead. Empirically, the point is moot: the ABO is not available for most firms in recent years, because they are no longer required to report it in the footnotes to their financial statements. 
Our main balance sheet variable, net pension assets per share, is defined as the difference between plan assets and the projected benefit obligation, divided by the number of shares outstanding. Our discussion thus far presumes that the market values of pension assets and liabilities reported in the notes to the financial statements are seen as accurate. Measuring the market value of assets is relatively straightforward, but calculating the present value of pension liabilities requires some important assumptions, including an assumed discount rate, as discussed earlier, and an assumed rate of future salary increases for covered employees. Although the FASB's guidance on the discount rate seems economically sound, firms retain some leeway in choosing it; thus the present value of liabilities reported in the financial statements could understate (or overstate) the true value. That said, it appears that most firms choose a reasonable discount rate, and we do not observe many firms changing their assumed discount rate in ways unrelated to changes in market conditions. We are therefore comfortable with a maintained assumption that markedto-market net pension assets is a good measure of the firm's pension exposure.

As discussed earlier, the component of pension cost related to the net financing of pension benefits is the NPPC excluding the service cost, a net value that can be positive or negative and is hereafter labeled pension earnings. To conform to the valuation model, pension earnings is converted to an after-tax per-share basis as follows:

pension $\mathrm{EPS}=0.65 \times(\mathrm{NPPC}-$ service $\cos \mathrm{t}) /$ number of shares.

Because we cannot directly measure expected pension earnings, we use pension earnings from the year recently ended (two to eight months earlier) as a proxy. We then define core earnings as expected current-year earnings (from $\mathrm{I} / \mathrm{B} / \mathrm{E} / \mathrm{S}$ ) minus actual pension earnings from the previous year: core EPS $=$ EPS - pension EPS.

\section{Sample Statistics on Pension Exposure}

Figure 2 provides a perspective on the sample variation in pension plan balance sheet exposure for firms with DB plans. The value of net pension assets is plotted by year as a percentage of the sponsoring firm's market equity value. Each vertical bar plots the cross-sectional range of pension 
Figure 2. Value of Net Pension Assets as a Share of Sponsor Equity Market Value, 1993-2001

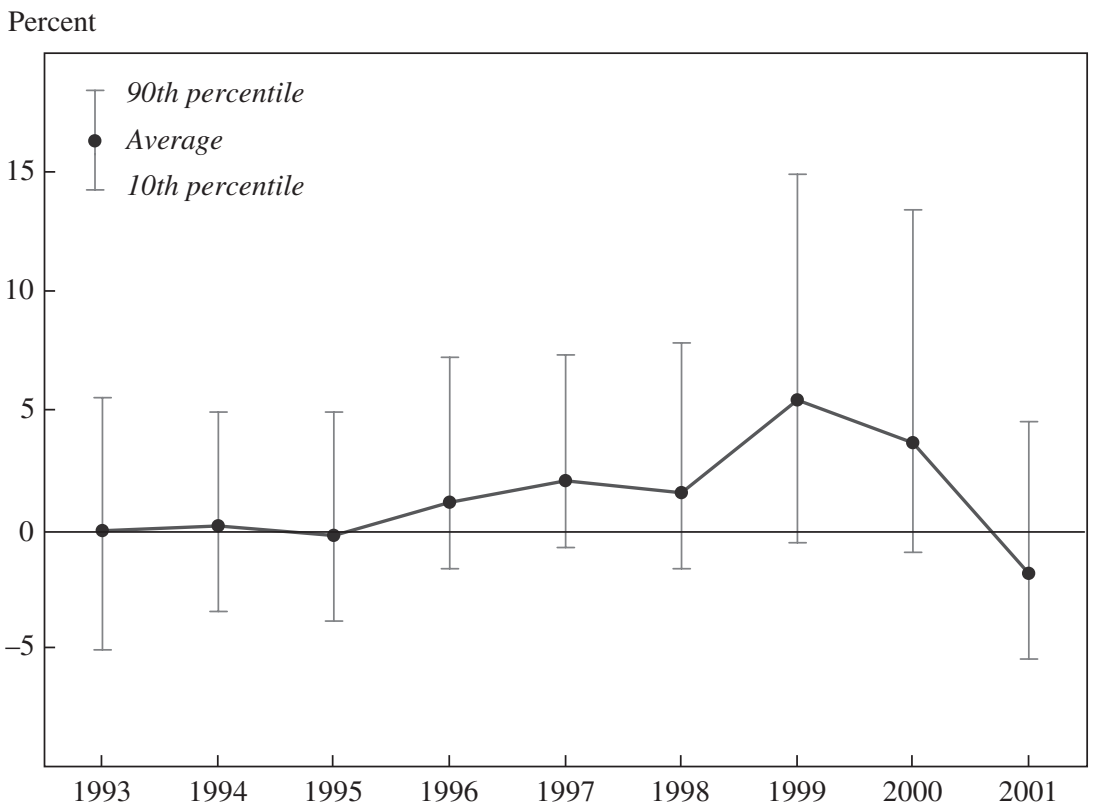

Source: Compustat and I/B/E/S.

a. Calculated for S\&P 500 firms with DB pension plans that satisfy the data criteria for analysis, on average 379 firms per year. Net pension assets equals the fair market value of plan assets less the present value of obligations.

net asset exposures, from the 10th to the 90th percentile, and the solid circles plot the average exposure, in the indicated year. In 1995 the distribution of net pension values was centered near zero but ranged from about -4 percent of firm market value at the 10 th percentile to 5 percent at the 90th percentile. By 1999 the positive end of the distribution had shifted substantially higher, putting the 90th percentile exposure at nearly 15 percent. However, after two years of declining stock prices and interest rates, the distribution of pension exposures at the end of 2001 had shifted back to near its sample-period lows, with the average firm now experiencing a drag from its pension plan.

Figure 3 shows analogous statistics for pension earnings as a percentage of expected total earnings. In every year the distribution of pension earnings is seen to be centered in positive territory; however, as with the 
Figure 3. Pension Earnings as a Share of Expected Total Earnings, 1993-2001 ${ }^{\text {a }}$

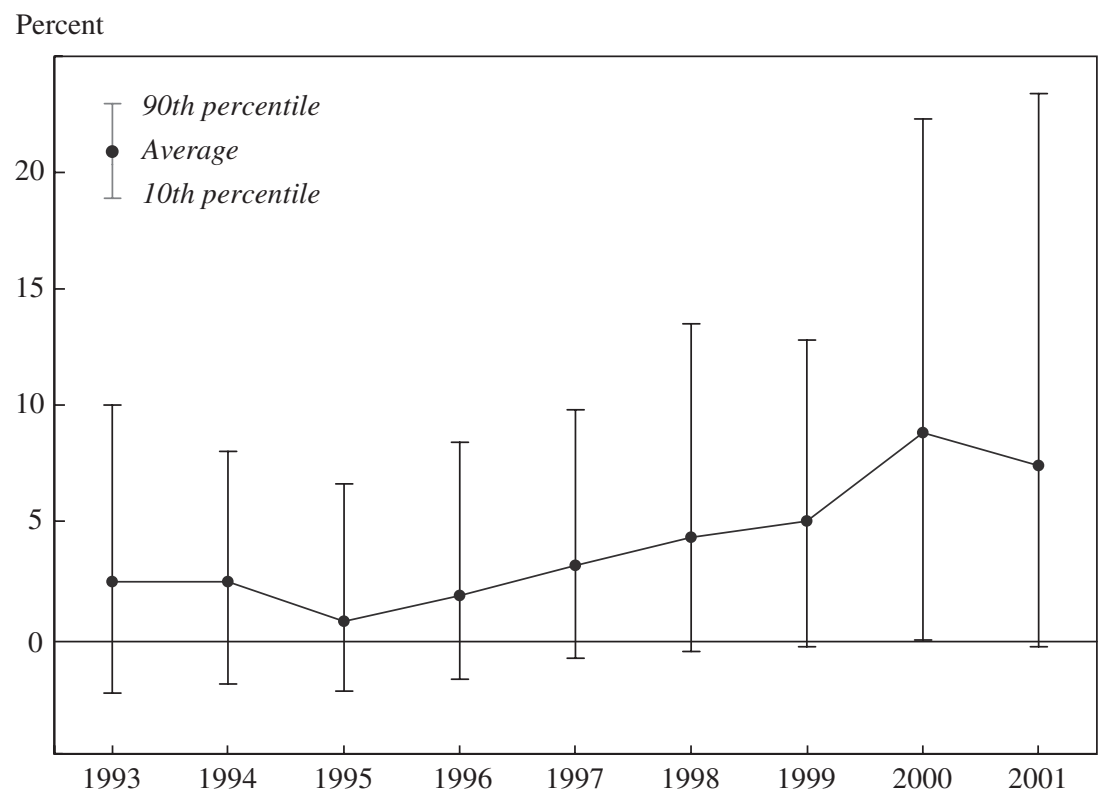

Source: Compustat and I/B/E/S.

a. Calculated for the same sample as in figure 2. Pension earnings is defined as (after-tax) net periodic pension cost minus service cost. Expected earnings is the consensus forecast of earnings in the following year.

net asset values, the top of the range of pension earnings exposures rose markedly during the late 1990s. By 2000 pension earnings accounted for about 9 percent of the average firm's expected earnings, and roughly 22 percent of those of firms at the 90th percentile. At the end of 2001, the average boost from pension earnings remained quite high, as accounting earnings continued to benefit from the amortization of high returns in previous years. Indeed, for the 90th-percentile firm, pension earnings in 2001 accounted for nearly 25 percent of total expected earnings.

These two measures of pension plan value were clearly at odds in 2000 and 2001, and the conflict was largely driven by the five-year amortization of gains. Table 2 conveys the subtler and potentially more pervasive conflict between pension earnings and plan fair market value. The table shows, for each year, the sample aggregate ratio of year-end net pension value to that year's pension earnings. If one were to think about valuation in terms of a price-earnings ratio, this ratio would indicate the appropriate 
Table 2. Aggregate Net Pension Assets, Pension Earnings, and Price-Earnings Ratios of S\&P 500 Firms with Defined-Benefit Pension Plans, 1993-2001 ${ }^{\text {a }}$

\begin{tabular}{ccccc}
\hline Year & $\begin{array}{c}\text { Net pension } \\
\text { assets } \\
\text { (billions of } \\
\text { dollars) }\end{array}$ & $\begin{array}{c}\text { Pension } \\
\text { earnings } \\
\text { (billions } \\
\text { dollars) }\end{array}$ & $\begin{array}{c}\text { Ratio of net } \\
\text { pension assets } \\
\text { to pension } \\
\text { earnings }\end{array}$ & $\begin{array}{c}\text { Price- } \\
\text { earnings } \\
\text { ratio }^{\text {c }}\end{array}$ \\
\hline 1993 & -14 & 2.7 & -5.2 & 15.9 \\
1994 & 14 & 3.8 & 3.7 & 15.7 \\
1995 & 18 & 3.9 & 4.6 & 16.5 \\
1996 & 74 & 5.6 & 13.2 & 19.2 \\
1997 & 138 & 8.5 & 16.2 & 23.3 \\
1998 & 121 & 11.1 & 10.9 & 26.8 \\
1999 & 251 & 16.3 & 15.4 & 23.1 \\
2000 & 187 & 20.6 & 9.1 & 21.7 \\
2001 & -2 & 20.4 & -0.1 & 20.7 \\
\hline
\end{tabular}

Source: Compustat and I/B/E/S data.

a. Statistics are calculated for S\&P 500 firms with defined-benefit pensions that satisfy our data criteria for analysis (on average about 370 firms a year).

b. Net periodic pension cost minus service cost (as defined in table 1) after tax.

c. Market value divided by annual net operating earnings in the previous year. Operating earnings are from I/B/E/S and represent the views of securities analysts; this measure often differs from (is usually higher than) S\&P's "reported earnings."

average "multiple" at which pension earnings should have been valued in any given year. For instance, at the end of 1997, the actual value of net pension assets totaled $\$ 138$ billion. That year pension earnings totaled $\$ 8.5$ billion, and the ratio of these two figures is 16.2 . Thus, roughly speaking, if at the end of 1997 investors had valued firms' pension earnings at a multiple of 16.2, the effect on market value would have been no different than if they had instead used the value of net pension asset positions reported in the footnotes to that year's financial statements.

The last column shows the aggregate annual price-earnings ratio for those same firms, that is, the ratio of their year-end equity market value to that year's earnings. In 1997, for instance, this ratio is 23.3, well above the 1997 ratio of pension net asset value to pension earnings. Clearly, if investors did not distinguish between pension earnings and core earnings, but instead valued them at the same multiple, then firms' pension earnings are likely to have been overvalued. The most glaring disparity, of course, is at the end of 2001. By then the aggregate value of net pension positions had plunged to a negative $\$ 2$ billion, while pension earnings for these firms totaled $\$ 20.4$ billion. At that point in time, naively valuing pension earnings, rather than taking account of pension net asset positions, would almost surely have led to nontrivial valuation errors. 
Table 3. Correlations between Pension Earnings and Net Pension Assets, 1995, 1999, and $2001^{\mathrm{a}}$

\begin{tabular}{llcr}
\hline & \multicolumn{3}{c}{ Net pension assets $^{\mathrm{c}}$} \\
\cline { 2 - 4 } Pension EPS $^{\mathrm{b}}$ & 1995 & 1999 & 2001 \\
\hline 1995 & 0.90 & 0.39 & 0.15 \\
1999 & 0.41 & 0.77 & -0.04 \\
2001 & 0.21 & 0.63 & -0.35 \\
\hline
\end{tabular}

Source: Authors' calculations using data from Compustat and I/B/E/S.

a. Calculated for S\&P 500 firms with defined-benefit pensions that satisfy our data criteria for analysis in the indicated year. For these calculations only, both net pension assets and pension EPS are normalized by the firm's stock price, to remove any spurious correlation induced by cross-sectional differences in scale.

b. After-tax net periodic pension cost minus service cost, per share.

c. Fair market value of plan assets less the present value of obligations, per share, at the end of the fiscal year.

Some perspective on the cross-sectional information conveyed by pension earnings is provided in table 3, which focuses on data from 1995, 1999, and 2001. The year-specific correlation between pension earnings and net pension value, each normalized by firm market value to remove any scale effects, is shown by the numbers along the diagonal. This correlation is highest in 1995, at 0.9, edges lower in 1999, and actually turns negative in 2001. The mismatch of information in 2001 is also reflected by the strong positive (off-diagonal) correlation between pension earnings in 2001 and net pension value in 1999.

\section{Results of Empirical Tests}

\section{Testing the Transparent versus the Opaque}

\section{View of Pension Valuation}

As discussed earlier, in the transparent view of pension valuation, the market incorporates the value of net pension assets directly. In the opaque view, the market prices net pension assets only indirectly, by valuing the pension-related accruals booked in accordance with FAS 87 . We estimate equations 3 and 4 in order to test which of these two hypotheses better explains actual firm values; table 4 shows the results, with robust standard errors reported below the coefficient estimates. All regressions include semiannual time dummies and, except where noted otherwise, use the full panel of observations. 
Table 4. Stock Price Regressions Testing the Transparent Model against the Opaque Model $^{\mathrm{a}}$

\begin{tabular}{|c|c|c|c|c|c|c|c|}
\hline \multirow[b]{2}{*}{ Independent variable } & \multicolumn{7}{|c|}{ Regression specification } \\
\hline & $4-1$ & $4-2$ & $4-3$ & $4-4$ & $4-5$ & $4-6$ & $4-7$ \\
\hline Core EPS ${ }^{b}$ & $\begin{array}{c}9.22 \\
(0.30)\end{array}$ & $\begin{array}{c}9.26 \\
(0.30)\end{array}$ & $\begin{array}{c}8.99 \\
(0.31)\end{array}$ & $\begin{array}{c}9.26 \\
(0.30)\end{array}$ & $\begin{array}{c}9.83 \\
(0.34)\end{array}$ & $\begin{array}{c}8.38 \\
(0.39)\end{array}$ & $\begin{array}{c}8.57 \\
(0.40)\end{array}$ \\
\hline Pension EPS & & $\begin{array}{l}11.02 \\
(1.72)\end{array}$ & $\begin{array}{c}8.62 \\
(1.83)\end{array}$ & $\begin{array}{l}10.81 \\
(1.20)\end{array}$ & & & $\begin{array}{c}8.37 \\
(1.89)\end{array}$ \\
\hline Net pension assets ${ }^{c}$ & $\begin{array}{c}0.76 \\
(0.10)\end{array}$ & $\begin{array}{l}-0.02 \\
(0.15)\end{array}$ & $\begin{array}{c}0.14 \\
(0.17)\end{array}$ & & $\begin{array}{l}-0.12 \\
(0.14)\end{array}$ & $\begin{array}{l}-0.09 \\
(0.14)\end{array}$ & $\begin{array}{c}-0.44 \\
(0.17)\end{array}$ \\
\hline Pension dummy ${ }^{\mathrm{d}}$ & $\begin{array}{c}0.83 \\
(0.50)\end{array}$ & $\begin{array}{c}0.44 \\
(0.51)\end{array}$ & $\begin{array}{c}1.07 \\
(0.52)\end{array}$ & $\begin{array}{c}0.45 \\
(0.51)\end{array}$ & $\begin{array}{c}0.30 \\
(0.64)\end{array}$ & & \\
\hline Core book value & $\begin{array}{c}0.15 \\
(0.04)\end{array}$ & $\begin{array}{c}0.13 \\
(0.04)\end{array}$ & $\begin{array}{c}0.12 \\
(0.04)\end{array}$ & $\begin{array}{c}0.13 \\
(0.04)\end{array}$ & $\begin{array}{c}0.09 \\
(0.04)\end{array}$ & $\begin{array}{c}0.26 \\
(0.06)\end{array}$ & $\begin{array}{c}0.27 \\
(0.06)\end{array}$ \\
\hline Growth forecast ${ }^{\mathrm{f}}$ & $\begin{array}{c}0.94 \\
(0.10)\end{array}$ & $\begin{array}{c}0.93 \\
(0.10)\end{array}$ & $\begin{array}{c}1.06 \\
(0.11)\end{array}$ & $\begin{array}{c}0.93 \\
(0.10)\end{array}$ & $\begin{array}{c}1.03 \\
(0.12)\end{array}$ & $\begin{array}{c}0.99 \\
(0.10)\end{array}$ & $\begin{array}{c}0.97 \\
(0.10)\end{array}$ \\
\hline $\begin{array}{l}\text { Lagged net } \\
\text { pension assets }\end{array}$ & & & & & $\begin{array}{c}0.63 \\
(0.19)\end{array}$ & & \\
\hline $\begin{array}{l}\text { Twice-lagged net } \\
\text { pension assets }\end{array}$ & & & & & $\begin{array}{c}0.53 \\
(0.19)\end{array}$ & & \\
\hline $\begin{array}{l}\text { Summary statistics: } \\
\text { Adiusted } R^{2}\end{array}$ & 0.621 & 0.628 & 0.630 & & & .800 & 0.802 \\
\hline $\begin{array}{l}\text { Root mean square } \\
\text { error }\end{array}$ & 12.44 & 12.34 & 11.82 & 12.33 & 13.33 & 9.67 & 9.63 \\
\hline $\begin{array}{l}\text { Source: Authors' regression } \\
\text { a. The dependent variable is } \\
\text { cases except column } 4-3 \text {, wher } \\
\text { errors are shown in parentheses } \\
\text { b. Expected current-year ea } \\
\text { (except in column } 4-3 \text {, where p } \\
\text { c. Defined as in table } 3 \text {. } \\
\text { d. Equals } 1 \text { if the firm has a } \\
\text { e. Equity book value less the } \\
\text { f. Median analyst forecast of }\end{array}$ & $\begin{array}{l}\text { the stock p } \\
\text { re it is apprc } \\
\text { rnings per s } \\
\text { ension EPS } \\
\text { DB plan, an } \\
\text { e book value }\end{array}$ & $\begin{array}{l}\text { a few mont } \\
\text { imately } 3,800 \\
\text { that in the } \mathrm{cu} \\
0 \text { otherwise. } \\
\text { f net pension }\end{array}$ & $\begin{array}{l}\text { All regress } \\
\text { (S) minus } \\
\text { (ent year). }\end{array}$ & $\begin{array}{l}\text { ff the firm } \\
\text { sinclude s } \\
\text { sion EPS }\end{array}$ & $\begin{array}{l}\text { scal year. T } \\
\text { iannual tim } \\
\text { ined as in } 1\end{array}$ & $\begin{array}{l}\text { ample siz } \\
\text { immies. } \\
\text { 3) in the }\end{array}$ & $\begin{array}{l}4,359 \text { in all } \\
\text { st standard } \\
\text { vious year }\end{array}$ \\
\hline
\end{tabular}

The initial specification, reported in column 4-1 of the table, assumes the transparent view (modeled by equation 3 ), which holds that the value of net pension assets influences the stock price, whereas that of pension earnings is superfluous and thus excluded from the equation. At first blush the results appear to confirm the predictions of the transparent model: the coefficient on net pension assets is 0.76 , with a standard error of 0.10 , implying that an additional dollar of value in net pension assets per share raises the firm's stock price by 76 cents. This point estimate falls squarely within the range predicted by the transparent model.

The estimated effects of the other variables on firm value are quite reasonable. The coefficient on expected core EPS is estimated quite precisely 
and suggests that an additional dollar in expected current-year core earnings raises a firm's stock price by $\$ 9.22$ on average. The coefficient on core book value, again defined as book value per share excluding the book value of net pension assets per share, is positive and significant as expected. The median analyst forecast of each firm's long-term growth is included in the regression and has a positive and significant effect on stock price. Because the existence of a pension plan is likely to be correlated with certain omitted firm characteristics, such as firm age, that are potentially correlated with earnings dynamics, we also include a dummy variable to control for the existence of a DB pension plan; however, the coefficient on this variable is insignificant.

Although table 4 does not report the results, we tested a similar specification in which pension assets and obligations were entered separately in the regression, allowing a test of our restriction that net pension assets is a sufficient statistic for the two sides of the pension balance sheet. In this regression the coefficient estimates on pension assets and obligations were 0.78 and -0.80 , respectively, and therefore we can easily accept the restriction imposed in the first regression; that is, net pension assets is a sufficient statistic for characterizing the valuation effect of the pension plan balance sheet information as reported in the footnotes of company financial statements.

To test the transparent model against the opaque model, we next estimate equation 4, and column 4-2 of table 4 shows the results. Here we add pension EPS, defined as pension earnings per share in the year just ended, our primary proxy for expected pension earnings. The estimated coefficient on pension EPS is 11.02, and it is both statistically significant and a bit larger than the coefficient on core EPS. The coefficient on core EPS is little changed from its value in column 4-1. Strikingly, the coefficient on net pension assets falls to zero, which constitutes a rejection of the transparent view of pension valuation. Given this result, a reasonable interpretation of the estimated effect of net pension assets in the initial specification is that it was spurious, a consequence of its correlation with the omitted variable, namely, pension earnings.

In estimating equation 4 as a test of the two models of pension valuation, we are treating the transparent model as if it were nested within the opaque model. Alternatively, these two models could be viewed as not nested. In that case the results presented in column 4-2 would not be the 
relevant test. ${ }^{24}$ Following procedures recommended by Russell Davidson and James MacKinnon, ${ }^{25}$ we perform a joint test of the transparent and opaque models by taking the fitted values from the estimation of equation 3 and including them in place of net pension assets in the estimation of equation 4. Significance of the fitted values would constitute evidence in favor of the transparent model. We perform this test and again reject the transparent model in favor of the opaque model.

To examine the robustness of our rejection of the transparent model, we undertook a number of additional experiments. We estimated equations 3 and 4 on each of nine annual cross sections separately, using robust regression. As table 5 shows, the transparent model is easily rejected in eight of the nine annual samples. Only in the 1998 sample does the transparent model win out, with net pension assets remaining significant at the 5 percent level when pension earnings was included. Perhaps the most convincing evidence is the fact that the opaque model clearly dominates in the 2000 and 2001 cross sections, when NPA and pension earnings were diverging.

In another sensitivity test, shown in column 4-3 of table 4, we examine whether these results are sensitive to our chosen proxy for expected pension earnings (pension EPS). Here, rather than use actual pension earnings from the year just ended as the proxy for expected current-year pension earnings, we use the realized value of current-year pension earnings. This amounts to assuming perfect foresight on the part of investors, which might not be unreasonable given that the value of pension earnings is to a great extent predetermined as of the beginning of the year. The downside is that using this proxy reduces the sample size, because we lose the last observation on each firm, including the entire 2001 sample. Nonetheless, the results are little changed: the coefficient on net pension assets is again very small and statistically insignificant, whereas the coefficient on pension earnings is a bit smaller than before but, again, close to the coefficient on core earnings.

Column 4-4 presents the results from estimating the pure opaque model. Here we return to our baseline proxy for expected pension earnings and

24. Essentially, if the models are not nested, then the parameters on the independent variables that the models have in common are not separately identifiable in this regression.

25. Davidson and MacKinnon (1981). 


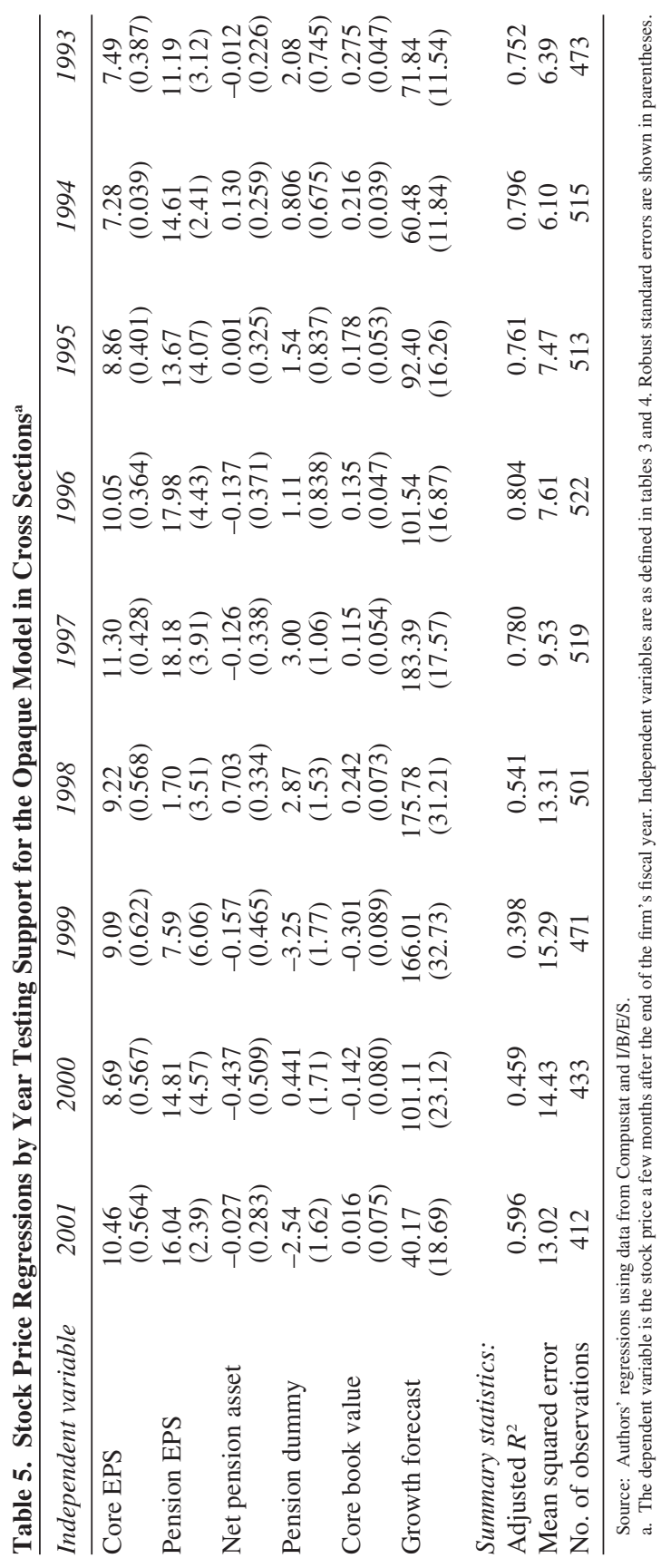


drop net pension assets from the regression, which should raise the precision of the coefficient estimate on pension earnings and allow for a cleaner comparison of the coefficients on the two components of earnings. We view this as our benchmark regression for subsequent tests of the relative valuation effects of core and pension earnings. As expected, the coefficient on pension earnings, at 10.81, is little changed from column 4-2, and its standard error drops.

As discussed earlier, past returns are only gradually amortized into the accounting measure of assets used to calculate expected returns on plan assets. Consequently, if the market focused only on reported pension earnings, it presumably would be using stale information. We test this interpretation in column 4-5, which shows the results of estimating the transparent model (equation 3) but with the lagged and twice-lagged value of net pension assets included in the set of regressors. As shown, both lagged variables have large and significant coefficients, whereas the current value of net pension assets is now insignificant, consistent with our interpretation that investors are valuing firms based on the out-of-date information on net pension plan value reflected in pension earnings.

In the last two columns we reestimate equations 3 and 4, but with firm fixed effects. Here the regression gauges the effects of within-firm variation over time, which makes the estimated effects quite sensitive to timing. Indeed, in contrast to column 4-1, the coefficient on the net pension assets in column 4-6 is effectively zero, and, when pension EPS is included (column 4-7), net pension assets has a negative marginal effect on stock price. The fixed effects regressions thus provide rather compelling support for the opaque view of DB pension valuation. ${ }^{26}$

\section{The Market Valuation of Pension Earnings}

Because our results support the hypothesis that investors price the contribution of a firm's pension plan to firm value by looking at the associated stream of accounting earnings, we next consider whether this result necessarily implies mispricing. Conceivably, investors might be extracting the necessary information from pension accruals and valuing pension

26. Because of the potential for disproportionate influences from outliers, the regressions in table 3 were also estimated using robust regression, which iterates after excluding outliers. The coefficient estimates are quite similar (although standard errors appear much smaller and are not robust against heteroskedasticity; results not shown), leaving our conclusions intact. 
plans in a way that is reasonably consistent with the underlying net asset value. One sign of mispricing would be if the market appeared to value pension earnings at the same multiple as core earnings. This not only would suggest a failure to differentiate, but would also mean that pension earnings are overvalued, since, as table 2 showed, the typical firm's ratio of net pension value to pension earnings tends to be about half the ratio of its market value to its earnings (its price-earnings ratio). In tables 6 and 7 we stress-test our finding (in column 4-4 of table 4) that a dollar of pension earnings is valued the same as a dollar of core earnings.

In the first test we reestimate the opaque model allowing for yearspecific coefficients on the two earnings components. Those coefficient estimates and their standard errors are reported in table 6. As shown, the coefficient on pension earnings is as large as or larger than the core earnings coefficient in every year except 1998 and 1999. The coefficient on pension earnings is statistically smaller, however, only in 1999, a year that also has an unusually low core earnings coefficient. It is perhaps not surprising that standard valuation models perform relatively poorly at the end of 1999, given the scant attention that the market seemed to pay to fundamentals at the time. Perhaps the most interesting result is the 2001 coefficient on pension earnings, which is a relatively high 14.9, despite the fact that pension earnings were an extremely poor signal of the underlying net pension value that year. Thus the conclusion that pension earnings are valued as highly as core earnings holds up when the source of identification is primarily cross-sectional.

Table 7 presents a further set of sensitivity tests. The regression reported in column 7-1 adds a term that interacts the analyst growth forecast and expected current-year earnings per share (core EPS + pension EPS) within the benchmark opaque model, to allow for a nonlinear effect of growth expectations on firm value. Interacting growth expectations

Table 6. Stock Price Regressions Interacting Earnings Components with Years ${ }^{\mathrm{a}}$

\begin{tabular}{lccccccccc}
\hline $\begin{array}{l}\text { Earnings } \\
\text { component }\end{array}$ & 1993 & 1994 & 1995 & 1996 & 1997 & 1998 & 1999 & 2000 & 2001 \\
\hline Core EPS & 9.0 & 8.1 & 9.7 & 10.4 & 12.5 & 9.9 & 7.1 & 7.9 & 10.0 \\
& $(0.8)$ & $(0.7)$ & $(0.5)$ & $(0.6)$ & $(0.8)$ & $(0.8)$ & $(0.8)$ & $(0.6)$ & $(0.6)$ \\
Pension EPS & 10.4 & 13.2 & 14.1 & 18.4 & 15.3 & 8.1 & 4.0 & 10.2 & 14.9 \\
& $(2.0)$ & $(2.5)$ & $(1.8)$ & $(2.9)$ & $(2.3)$ & $(2.2)$ & $(2.2)$ & $(1.7)$ & $(3.1)$ \\
\hline
\end{tabular}

Source: Authors' regressions using data from Compustat and I/B/E/S.

a. Results are for a regression specification identical to that in column 4-4 in table 4, except that the two earnings components are interacted with year dummies. The $R^{2}$ of the regression is 0.642 . 
Table 7. Stock Price Regressions Gauging the Relative Valuation of Core and Pension EPS ${ }^{\mathrm{a}}$

\begin{tabular}{|c|c|c|c|c|c|c|c|}
\hline \multirow[b]{2}{*}{ Independent variable } & \multicolumn{7}{|c|}{ Regression specification } \\
\hline & $7-1$ & $7-2$ & $7-3$ & $7-4$ & $7-5$ & $7-6$ & $7-7$ \\
\hline Core EPS & $\begin{array}{l}9.25 \\
(0.30)\end{array}$ & & & $\begin{array}{c}9.03 \\
(0.31)\end{array}$ & $\begin{array}{l}12.12 \\
(0.62)\end{array}$ & $\begin{array}{c}7.53 \\
(0.41)\end{array}$ & $\begin{array}{c}9.63 \\
(0.90)\end{array}$ \\
\hline Pension EPS & $\begin{array}{l}10.72 \\
(1.18)\end{array}$ & $\begin{array}{l}10.03 \\
(1.24)\end{array}$ & $\begin{array}{c}9.69 \\
(1.16)\end{array}$ & $\begin{array}{l}12.85 \\
(1.34)\end{array}$ & $\begin{array}{l}15.36 \\
(3.17)\end{array}$ & $\begin{array}{c}7.96 \\
(1.65)\end{array}$ & $\begin{array}{l}14.04 \\
(4.29)\end{array}$ \\
\hline Pension dummy & $\begin{array}{c}0.43 \\
(0.50)\end{array}$ & $\begin{array}{l}1.10 \\
(0.55)\end{array}$ & $\begin{array}{c}0.21 \\
(0.48)\end{array}$ & $\begin{array}{l}2.25 \\
(0.53)\end{array}$ & $\begin{array}{c}0.68 \\
(0.61)\end{array}$ & & \\
\hline Core book value & $\begin{array}{c}0.13 \\
(0.04)\end{array}$ & $\begin{array}{l}0.23 \\
(0.04)\end{array}$ & $\begin{array}{c}0.02 \\
(0.04)\end{array}$ & $\begin{array}{l}0.30 \\
(0.04)\end{array}$ & $\begin{array}{c}0.21 \\
(0.05)\end{array}$ & $\begin{array}{c}0.37 \\
(0.07)\end{array}$ & $\begin{array}{c}0.29 \\
(0.09)\end{array}$ \\
\hline Growth forecast & $\begin{array}{l}0.72 \\
(0.14)\end{array}$ & $\begin{array}{l}1.11 \\
(0.11)\end{array}$ & $\begin{array}{c}0.80 \\
(0.09)\end{array}$ & $\begin{array}{l}1.07 \\
(0.12)\end{array}$ & $\begin{array}{c}0.88 \\
(0.11)\end{array}$ & $\begin{array}{l}1.24 \\
(0.11)\end{array}$ & $\begin{array}{c}0.94 \\
(0.12)\end{array}$ \\
\hline Growth $\times$ EPS & $\begin{array}{c}0.17 \\
(0.10)\end{array}$ & & & & & & \\
\hline Core EPS $(-1)^{b}$ & & $\begin{array}{c}8.11 \\
(0.36)\end{array}$ & & & & & \\
\hline Core EPS $(+1)^{\mathrm{c}}$ & & & $\begin{array}{c}9.33 \\
(0.28)\end{array}$ & & & & \\
\hline \multicolumn{8}{|l|}{ Summary statistics: } \\
\hline Adjusted $R^{2}$ & 0.628 & 0.559 & 0.652 & 0.784 & 0.667 & 0.868 & 0.781 \\
\hline $\begin{array}{l}\text { Root mean square } \\
\text { error }\end{array}$ & 12.33 & 13.45 & 11.92 & 9.32 & 11.80 & 7.81 & 10.25 \\
\hline
\end{tabular}

with total earnings effectively presumes that analysts' long-term growth forecasts apply to the total current earnings base; thus the effect of pension earnings is a little more difficult to parse out in this specification. In any case the estimated coefficient on the interaction term is only marginally significant, whereas the estimated effects of core EPS and pension EPS are still statistically equivalent and quite close to the coefficients in the benchmark opaque model. ${ }^{27}$

27. The growth forecast has been mean adjusted, so that adding its interaction with earnings does not have a level-shifting effect on the two noninteracted earnings variables, which makes it easier to compare results with specifications that exclude the interaction term. Like all the other specifications, this one was also estimated using robust regression. In that case the estimated interaction term is larger and highly significant; however, the coefficients on the two earnings components were little changed (results not shown). 
The specification reported in column 7-2 considers a more traditional implementation of the residual value framework. Here, we replace expected core earnings with actual lagged core earnings, core EPS(-1), calculated as total EPS minus pension EPS, both from the year just ended. Our data requirement that both total and core earnings be positive reduces the sample by 130 observations in this specification, to 4,229 firm-year observations. Using actual core earnings reduces the regression's adjusted $R^{2}$ and raises the root mean square error. Moreover, the coefficient on core EPS(-1), at 8.1, is a bit smaller than that on core EPS in the benchmark specifications. The coefficient on pension EPS is also a bit smaller here but significantly larger than the coefficient on core EPS(-1). This result is probably due to core earnings having a larger transitory component than pension earnings; using expected core earnings presumably dampens the influence of such transitory components.

In column 7-3 we present results based on yet another measure of core earnings. Here, core EPS $(+1)$ is constructed by subtracting pension EPS (in the year just ended) from the analyst forecast of next year's earnings. This more forward-looking measure might be an even better proxy for the perceived "trend" level of core earnings, since it should be influenced less by cyclical factors that could be at play in current-year forecasts. As shown, the adjusted $R^{2}$ for this specification is indeed somewhat higher, but the coefficient values and conclusions are essentially unchanged.

The fact that the coefficients on core earnings and pension earnings are statistically equivalent could indicate that investors do not distinguish between these two sources of earnings. Alternatively, investors might recognize the two disparate sources of earnings, but they just happen to price pension earnings at the same multiple as they price core earnings for the average firm. Differentiating between these possibilities might affect the interpretation of our results, or at least the particulars of any policy ramifications.

To discern whether investors recognize the difference between core earnings and pension earnings, we divide the sample into firms with high and firms with low price-earnings ratios based on each firm's median price-earnings ratio, measured for our sample as the stock price divided by expected current-year earnings per share. It is difficult to concoct a rational justification for the pension earnings of these two groups of firms to be valued differently. However, if investors are naively valuing pen- 
sion earnings, we would expect to see a larger multiple being applied to the pension earnings of firms with high price-earnings ratios. Columns 7-4 and 7-5 show the benchmark model estimates for the firms with low and firms with high price-earnings ratios, respectively.

As one would expect-almost by definition - the coefficient estimate on core EPS for firms with low price-earnings ratios is smaller than it is for those with high ratios: roughly 9 versus 12 . What is more interesting is that within each group the coefficient on pension earnings exceeds that on core earnings. Moreover, it appears that the pension earnings of the average high-priced firm are valued more highly than those of the average low-priced firm, although this difference is not statistically significant.

The final two columns in table 7 show the results from estimating a fixed effects model on the same two groups. The results here are more clear-cut: the coefficients on both core EPS and pension EPS are larger at high-priced firms than the respective coefficients at low-priced firms. Thus it would appear that investors implicitly extrapolate to the pension earnings of firms with high price-earnings ratios the more robust growth prospects these firms presumably enjoy in their core businesses. Taken together, these results reinforce our earlier conclusion that investors do not appropriately discount pension earnings.

\section{Estimating the Value of Pension Earnings \\ with a Dividend Discount Model}

One potential criticism of the inferences from table 7 is that they are model-dependent. Here we evaluate the relative contributions of core and pension earnings to firm value within a different model: a more traditional dividend discount-type model. With net pension assets dropped from the regression, there is less impetus to be bound to the standard Ohlson-style model and the consequent linear relation between market equity value, book value, and earnings. ${ }^{28}$

Instead, we consider a regression equation derived from the standard Gordon growth valuation model:

$$
P_{t}=d \frac{\mathrm{EPS}_{t}}{r-g},
$$

28. Ohlson (1995). 
where $d$ is the firm's dividend payout rate, $g$ is its long-run growth rate, $r$ is the discount rate, and EPS is current earnings per share. Taking logs of both sides yields

$$
\log P=\log d+\log \text { EPS }-\log (r-g) .
$$

Equation 6 is an appropriate valuation formula under the hypothesis that pension earnings are valued no differently from core earnings. However, to test this hypothesis, we first subtract the log of core earnings from both sides of the equation to obtain

$$
\log \frac{p}{\text { core EPS }}=\log d+\log \frac{\mathrm{EPS}}{\text { core EPS }}-\log (r-g) .
$$

The empirical implementation of this model is as follows:

$$
\log \frac{P}{\text { core EPS }}=b_{1} \log \frac{\mathrm{EPS}}{\text { core EPS }}+b_{2} \log d+b_{3} \log g+b \mathbf{z}+u,
$$

where $\mathbf{z}$ is a vector of time dummy variables that control for time variation in $r$, the required return on equity. Testing whether $b_{1}=1$ is equivalent to testing the hypothesis that the two earnings sources are identically priced. If investors valued only core earnings and ignored pension earnings, we would expect to find $b_{1}=0$. A coefficient between 0 and 1 would imply that, on average, investors place greater value on a dollar of core earnings than on a dollar of pension earnings. Our earlier tests (based on equation 4) suggest that $b_{1}$ might exceed unity, implying that pension earnings are, in effect, accorded a greater multiple than core earnings.

Table 8 shows results from estimating equation 8 , with robust standard errors shown in parentheses below the coefficient estimates. In addition to the variables from the model, each regression includes a control for firm size (the logarithm of firm assets) and a dummy variable indicating whether the firm has a DB pension plan. To the extent that the growth variable is an imperfect indicator of long-term growth expectations, the price-earnings ratio (the ratio of price to core earnings) could arguably be negatively related to firm size and the presence of a DB plan, because larger, older firms tend to be slower growing. Finally, all regressions include semiannual time dummies.

Column 8-1 in table 8 shows the results from the basic specification, where expected core earnings are based on current-year earnings fore- 
Table 8. Price-Earnings Ratio Regressions Quantifying the Valuation of Pension Earnings in a Dividend Discount Model $^{\mathrm{a}}$

\begin{tabular}{lccccc}
\hline & \multicolumn{5}{c}{ Regression specification } \\
\cline { 2 - 6 } Independent variable & $8-1$ & $8-2$ & $8-3$ & $8-4$ & $8-5$ \\
\hline Log [EPS/core EPS] & 1.22 & & 1.24 & 1.10 & 1.55 \\
& $(0.07)$ & & $(0.06)$ & $(0.07)$ & $(0.10)$ \\
Log [EPS(+1)/core EPS(+1)] & & 1.08 & & & \\
& & $(0.13)$ & & & \\
Log [dividend payout] & 0.21 & 0.16 & 0.54 & 0.17 & 0.22 \\
& $(0.03)$ & $(0.02)$ & $(0.05)$ & $(0.03)$ & $(0.04)$ \\
Log [growth forecast] & 0.63 & 0.51 & 0.39 & 0.26 & 0.80 \\
& $(0.03)$ & $(0.02)$ & $(0.04)$ & $(0.02)$ & $(0.06)$ \\
Log [total assets] & -0.05 & -0.04 & 0.02 & -0.04 & -0.01 \\
& $(0.01)$ & $(0.01)$ & $(0.02)$ & $(0.01)$ & $(0.01)$ \\
Pension dummy & -0.10 & -0.07 & & -0.02 & -0.07 \\
& $(0.02)$ & $(0.02)$ & & $(0.02)$ & $(0.03)$ \\
Constant & 2.47 & 1.89 & 3.29 & 3.03 & 1.19 \\
& $(0.13)$ & $(0.08)$ & $(0.35)$ & $(0.18)$ & $(0.16)$ \\
Summary statistics: & & & & & \\
Adjusted $R^{2}$ & 0.406 & 0.339 & 0.748 & 0.438 & 0.399 \\
Root mean square error & 0.453 & 0.389 & 0.316 & 0.338 & 0.456 \\
\hline
\end{tabular}

Source: Authors' regressions using data from Compustat and I/B/E/S.

a. The dependent variable is the logarithm of the ratio of the stock price to core EPS, taken a few months after the end of the fiscal year. Sample size is 4,359 in all specifications, and all regressions include semiannual time dummies. Robust standard errors are shown in parentheses. Definitions are as in tables 4 and 7 except where noted otherwise.

b. Logarithm of recent (annualized) dividends per share divided by EPS.

c. Logarithm of the book value of firm assets in the previous year.

casts. The coefficient on the logarithm of the total-to-core earnings ratio is 1.22. Given its small standard error, we can easily reject the hypothesis that this coefficient is less than 1.0. Thus we accept the hypothesis that the ratio of price to core earnings increases by at least 1 percent for a 1 percent increase in the ratio of total earnings to core earnings. This result reinforces our evidence from table 6 suggesting that investors value pension earnings at a multiple at least as great as that on core earnings, if not higher.

Coefficients on the other variables have the expected signs and are of reasonable magnitudes. The coefficient on the dividend payout rate is well below unity, which is to be expected if payout rates tend to revert back to some norm after being buffeted by shocks to earnings. ${ }^{29}$ The coefficient on the logarithm of the growth forecast is 0.63 , which implies that

29. As shown by Sharpe (2002), in a dynamic version of equation 8 in which the payout rate is assumed to revert toward some target level, the coefficient on the logarithm of 
a 10 percent increase in the growth forecast—say, from 10 to 11 -would boost the stock price by 6.3 percent. The pension dummy and firm size have negative coefficients, consistent with the presumption that larger firms and those with DB plans tend to have lower price-earnings ratios. Finally, the adjusted $R^{2}$ of the regression is 0.41 , indicating that the independent variables explain a good deal of the variation in the price-to-core earnings ratio.

Column 8-2 shows the results from estimating the same model, but using analyst forecasts of the subsequent year's earnings to gauge the expected level of core earnings. Here the coefficient estimate on the ratio of total to core earnings is 1.08 , which is not significantly different from 1 , suggesting that there is no difference in the multiple that investors place on core earnings versus pension earnings. The other coefficient estimates are similar to those in the first regression.

Column 8-3 shows the results of estimating a fixed effects version of the initial specification. Here the coefficient estimate on the earnings ratio is 1.24 , which is very close to the first result and confirms that the inference applies not only cross-sectionally but also to movements in a given firm's valuation over time. Coefficients on the other variables differ somewhat, but they again have the predicted sign and are of plausible magnitude. The addition of fixed effects yields a substantially tighter fit.

Columns 8-4 and 8-5 show results from estimating the model for the subsamples with low and high price-earnings ratios, respectively, with firms grouped according to their median ratio of price to total expected EPS. Paralleling the argument made earlier, if investors were valuing pension earnings appropriately, we would expect pension earnings to have a less than proportionate impact on the stock prices of high-priced firms, even if this were not the case for low-priced firms. On the contrary, the estimated coefficient of 1.55 on the ratio of total to core EPS for the highpriced group suggests that pension earnings have a greater effect than core earnings on the stock price of high-priced firms. We thus conclude that our earlier finding, that investors are valuing pension earnings at least as highly as core earnings and that they are possibly not even distinguishing between these sources of earnings, is robust across models of firm value.

the payout ought to be between 0 and 1 ; moreover, for plausible speeds of reversion, that coefficient is likely to fall in the lower end of this range. 


\section{Implications for Equity Mispricing}

In light of our main findings - that the market seems to ignore the pension balance sheet while placing at least as much value on pension earnings as on core earnings-we apply a fairly straightforward approach to estimate the consequent mispricing of sponsoring firms. To construct firm-level equity valuation errors, we first estimate our log price-earnings ratio model (equation 7) with the addition of time dummy variables and other controls used in the table 8 regressions. From the resultant coefficient estimates, we construct predicted price-earnings ratios for each firm in each year. Under the now-plausible assumption that investors do not differentiate between core and pension earnings, the increment to the stock price attributable to pension earnings is estimated by multiplying, for each firm in each year, the simulated price-earnings ratio by the corresponding value of pension earnings per share. Finally, the implied valuation error is calculated as the difference between this inferred actual increment to the stock price and the increment predicted by the transparent model of pension valuation, that is, the tax-adjusted value of net pension assets, $(1-T) \times$ NPA.

Figure 4 shows the results from two sets of such calculations that use alternative assumptions about the effective tax rate $T$. In each case we plot the annual range of pricing errors, from the 10th to the 90th percentile. The ranges plotted by the left-hand line in each pair are calculated under the assumption that $T=0$, whereas the right-hand lines show the results assuming $T=0.35$. For each simulation we also show the annual aggregate weighted-average pricing error for our pension sample, denoted by the solid circle, and the annual unweighted average pricing error, denoted by the hollow circle.

In both cases the most striking change over time is the rise of the top end of the range of valuation errors. In particular, the results suggest that, after the release of 2001 financial results (in May 2002 for most of the sample and November 2001 for the remainder), the shares of more than one-tenth of pension sponsors were at least 20 percent overvalued, and that of the average pension sponsor was about 10 percent overvalued. Of course, the dramatic rise in overvaluation errors in 2001 was driven largely by the plunge in the net asset value of pension plans while, by contrast, pension earnings barely fell. 
Figure 4. Estimated Valuation Errors as a Share of Firm Market Value, 1993-2001 ${ }^{\mathrm{a}}$

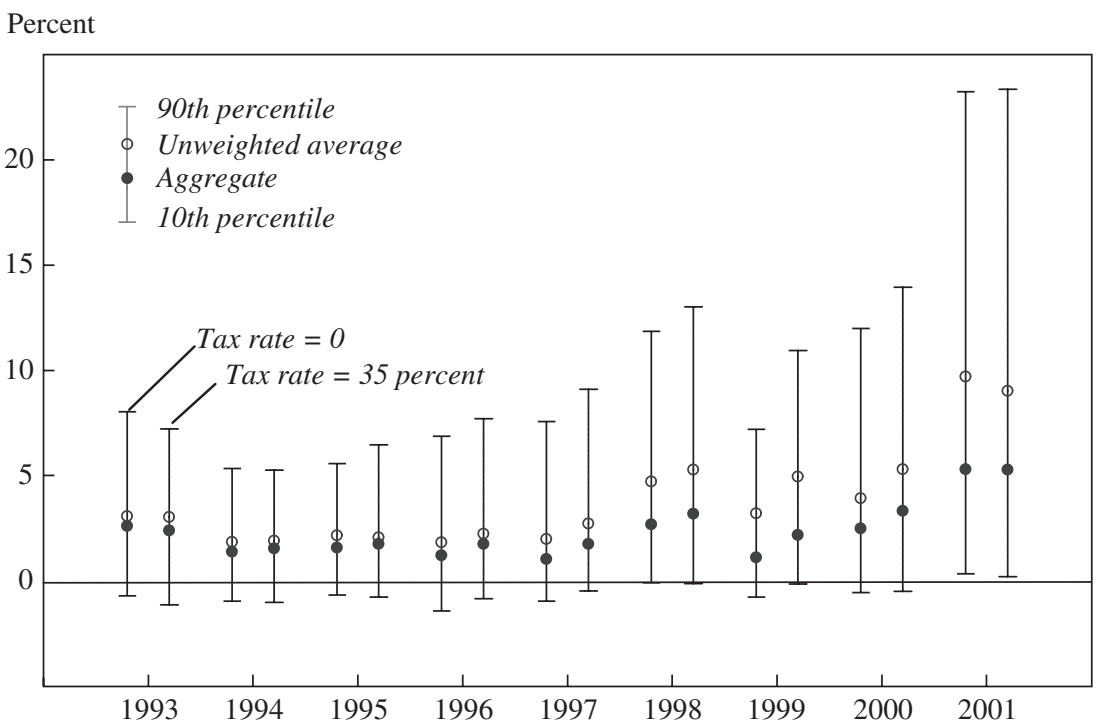

Source: Authors' regressions using data from Compustat and I/B/E/S

a. The implied valuation error is the increment to the stock price when pension earnings per share is multiplied by the earnings per share estimate from equation 7 , minus the increment predicted by the transparent valuation model in equation 3 .

Much less dramatic is the rise in estimated overvaluation in the aggregate, which reaches 5 percent by the end of $2001 .^{30}$ Indeed, the simulations suggest that pension accounting did not substantially add to any stock market bubble during the latter half of the 1990s. We note in passing, however, that our analysis considers only a "level effect" from higher pension earnings on equity prices. Another potential channel for the impact on stock prices is through growth expectations, that is, through the effect of actual growth on expected longer-term growth. As documented by Steven Sharpe, during the latter half of the 1990s the average nominal long-term growth forecast by analysts rose more than 3 percentage points, and stock prices were apparently quite sensitive to the beliefs reflected in those forecasts. ${ }^{31}$ If analysts and investors had extrapolated from the boost

30. Moreover, because the sample represents only about three-quarters of the S\&P 500 by market value, the implied mispricing error for the S\&P composite index was less than 4 percent after 2001. Of course, in terms of absolute dollars (about 4 percent of nearly $\$ 10$ trillion) the excess value is not insignificant.

31. Sharpe (2002). 
to actual earnings growth from pension plans in making their longer-term growth forecasts, then pension earnings could account for a larger share of the runup in stock prices.

Before concluding, we speculate on how the stock price effects of the swing in pension values might play out going forward, as the dismal "unexpected" returns of recent years are amortized into pension earnings. One fairly neutral approach involves projecting the path of pension earnings and pension net asset value under the assumption that, on average, companies earn their expected long-run return of 8 to 9 percent on their pension portfolios during 2003-06. In this scenario, amortization of the negative unexpected returns earned in 2000 through 2002 is complete by the end of 2006. In addition, we assume that companies continue making fairly large cash contributions to their pensions, at a rate of $\$ 30$ billion to $\$ 40$ billion a year, which in this scenario would bring the aggregate value of pension assets, net of obligations, back up near zero by the end of 2006.

Under these assumptions, the after-tax value of net pension assets (given an effective tax rate of 0.25 ) would follow a trajectory like that depicted by the solid line in figure 5. After dropping to around $-\$ 150$ billion in 2002, on balance, S\&P 500 net pension positions gradually move back toward full funding, reaching $-\$ 25$ billion by 2006 . At the same time, pension earnings, which are estimated to have declined from $\$ 20.5$ billion in 2001 to $\$ 16.0$ billion in 2002 , are projected to decline steadily to $-\$ 6.5$ billion by 2006 . If investors continue to value pension earnings at a market multiple of, say, 18, the trajectory of pension effects on the aggregate market value of sponsors' equity would look something like the dashed line in the figure. The overvaluation of pension plans, as measured by the gap between these two lines, is thus estimated to have risen a bit further in 2002, before reversing itself over subsequent years. By the end of the projection period, the sign of the gap reverses, reflecting overweighting of negative pension earnings by investors.

Of course, the range of possibilities is quite large. Moreover, the greater scrutiny now being given to pension accounting may already have begun to induce investment professionals to differentiate between core and pension earnings and devote greater attention to pension balance sheets. This trend is likely to be reinforced by companies with pension plans, as they try to convey to investors that any negative earnings momentum from their plan does not reflect poor health of their core business-an incentive that was not present on the upside of this cycle. 
Figure 5. Projected Net Pension Assets and Market Value of Pension

Earnings, 2001-06

Billions of dollars

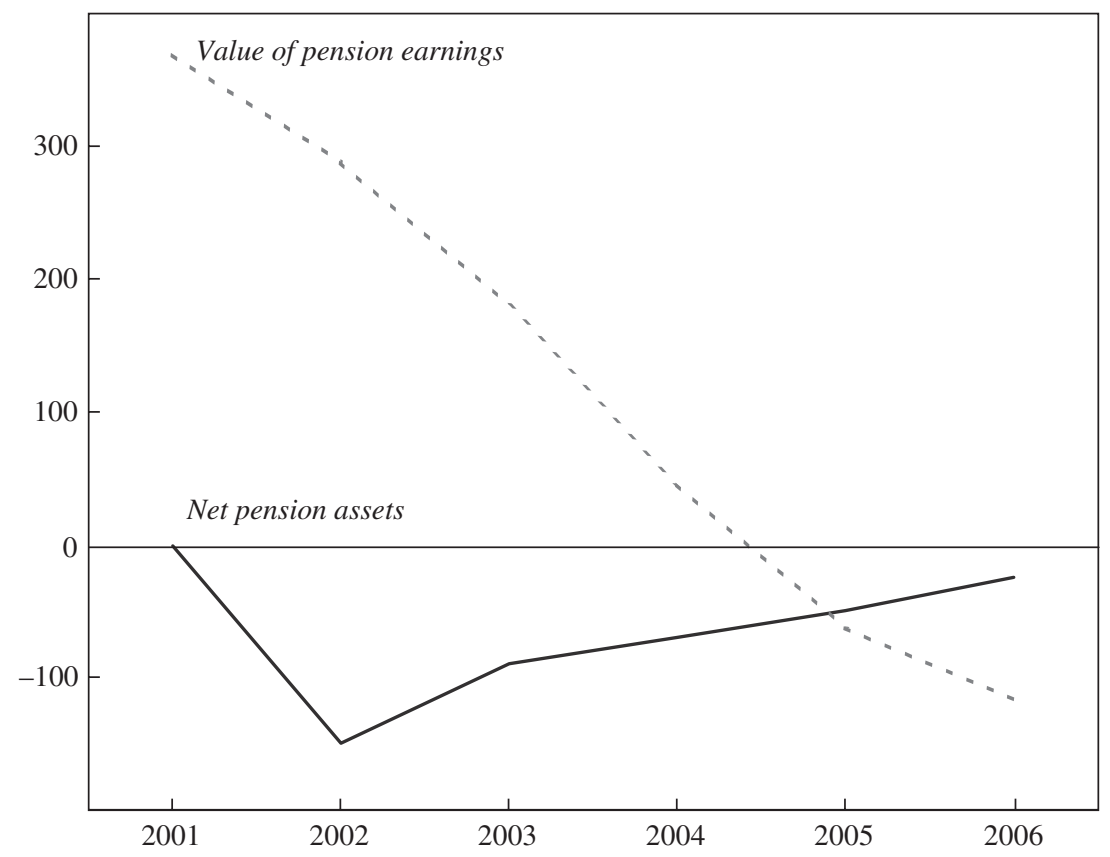

Source: Authors' regressions using data from Compustat and I/B/E/S

a. Net pension assets equals the projected market value of pension assets minus the projected pension benefit obligation assuming that pension portfolios earn 8.5 percent a year in 2003-06, and that companies make substantial annual cash contributions over these years. Value of pension earnings is projected by amortizing previous unexpected returns into market-related value under the same assumptions plus the assumption that pension earnings are valued at a multiple of 18 .

\section{Conclusions}

This study has examined how defined-benefit pension plans have affected the equity prices of sponsoring firms during the past ten years, a time when stock market-driven changes to the value of net pension obligations had a substantial effect on both the theoretical value of the sponsoring firm's balance sheet and the trajectory of its reported earnings. We tested whether investors value sponsors' DB pension exposures by looking at the fair market value of pension assets and obligations disclosed in the footnotes to their financial statements, or by looking at pension financing effects in their accounting earnings. 
We find that although accounting earnings and costs associated with pension plans are often a very misleading measure of the underlying value of net pension obligations, the market seems to have largely focused on these accruals. Moreover, the valuation that the market places on these pension-related accruals is at least as high as, if not higher than, the value it places on core earnings. An implication, which we calibrated, is that the stocks of a number of S\&P 500 companies that sponsor DB pension plans were substantially overvalued in recent years.

A broad implication of these findings-and one that would probably not surprise accountants as much as economists-is that accounting matters. Complicated distortions embedded in the bottom-line figures that are emphasized in financial statements and press releases can distort the market prices of equities substantially. This occurs even though the underlying details are disclosed in the footnotes to the financial statements, and thus are available to experts to more accurately gauge firm value. In particular, these findings provide support for complaints that the system of pension accounting introduced by FAS 87 should be reexamined and revised. Indeed, the Financial Accounting Standards Board has recently indicated its intention to seek more frequent and fuller disclosure of information on pension obligations and accruals and has announced a project to develop a new pension accounting standard. We expect that serious consideration will also be given to the broader question of whether pension accounting should move toward a mark-to-market approach, with pension gains and losses flowing transparently through firms' financial statements. 


\section{Comment and Discussion}

Mark J. Warshawsky: ${ }^{1}$ Pension accounting is a timely and important topic, because of the specific issue of measuring pension funding adequacy and because of the broader issue of financial accounting accuracy. (Of particular interest is the subissue of the appropriate discount rate to be used in calculating the pension liability.) Knowledge of these subjects has spread beyond the experts and into the broader public. The importance and relevance of this paper's results are further heightened by potentially even broader implications going beyond pension accounting to government budget accounting and Social Security reform. My comment will summarize the paper and offer some questions and suggestions to challenge the analysis.

The paper's main result is that the market mistakenly focuses on smoothed pension earnings, or expenses (as argued by the opaque hypothesis), rather than on net pension assets, or obligations (as argued by the transparent hypothesis), in establishing the effect of a defined-benefit pension plan on a firm's value. The analysis is based on Compustat and I/B/E/S data from 1993 to 2001 on the firms included in the S\&P 500 from December 1996 through 1998.

The authors primarily use a residual income model with both nested and nonnested tests of the transparent versus the opaque hypothesis. Pension earnings are defined on an after-tax, per-share basis net of pension service cost, where the after-tax measure is "hard-wired," that is, set by the authors' own formula. Net pension assets are defined as the market

1. The views expressed here are the author's own and do not necessarily represent the views of the Treasury Department or the administration. 
value of pension assets less the reported projected benefit obligation. (There is a difference between the projected benefit obligation and the accumulated benefit obligation, as I will discuss later.) A combined data set approach is used, with projected earnings and time dummies as independent variables. Annual cross sections, fixed effects, and the dividend discount model, however, are also included in the analysis to test for robustness. Various tests support the opaque hypothesis.

Some other results are also emphasized. One is that the market may be prone to overprice companies with defined-benefit plans because of the difference between the assumed rate of return on investment and the discount rate used to determine the present value of benefit obligations. Sample statistics in the paper imply that pension earnings are overvalued, at least when the market declines. The authors also find that firms with high ratios of stock price to core earnings also exhibit high ratios of stock price to pension earnings. Simulation results support significant overpricing of the upper range of the evaluation distribution.

The paper cites a significant recent professional literature, primarily from the accounting field, as well as some earlier papers. The timeline suggests a bit of an era effect in the literature. The early papers were written before FAS 87 went into effect and well before the issuance of FAS 106 on retiree health benefits accounting. Actual accounting standards for corporate DB pension plans were not yet in place, and therefore regression analysis was used to estimate the impact of disclosed net assets on valuation. In these cases there were no associated expenses, and hence the early literature may not be pertinent to the results in this paper.

A more relevant task is to reconcile the paper's results with papers written after FAS 87 went into effect; of these, the most significant work cited is that by Barth, Beaver, and Landsman, ${ }^{2}$ which arrives at a different result than the present authors. The analysis by Barth and her coauthors uses data from an earlier period, which leads me to suggest that the authors try to reconcile their differing results and to consider different three- to five-year periods to ensure the robustness of their results. Also cited is a very recent working paper by Brown, ${ }^{3}$ which focuses on actuarial assumptions and suggests their importance in firm valuation. I discuss the relevant discount rate information below.

2. Barth, Beaver, and Landsman (1992, 1993).

3. Brown (2002). 
It would be interesting to expand the analysis beyond the S\&P 500 and compare the results. There may also be a sample selection bias. The S\&P 500 continually adds new firms and, more significant, drops failing firms. For these failing firms, and for those the market thinks might be approaching failure, the projected benefit obligation becomes much less relevant than the accumulated benefit obligation, because the projection of future salary increases is not relevant. Also, when a firm is on a downward path, there may be a lag between this new, shrunken reality and its reflection in the retirement and cash distribution assumptions made by the firm's actuaries and accountants. The PBGC put option - the agency's guarantee of the firm's pension benefits - may become more relevant as the firm declines. But, ironically, the tax considerations may become less relevant, and the hardwired tax calculation employed here may be less accurate.

A very simple test of the authors' hypothesis may be possible. As the paper emphasizes, what is important for the calculation of pension expense is the assumed (expected) long-run rate of return on assets. The actual return on plan assets is disclosed, however, and the difference between this and the assumed return may be a significant variable in firm valuation, if the authors' hypothesis is true. Similarly, an examination of the nature of a pension trust may be warranted, and the composition of assets may be a significant variable, although this would require a more complex analysis.

The period the authors examine saw many financial restatements whose full relevance and significance may not yet have emerged. Was the accounting information that later appeared in the financial restatements available to the market when the prices that the authors used in their analysis were observed? Another potential missing variable is employee stock options. These became very popular during the period, and some believe they were not properly accounted for. Significant measurement problems may have arisen in other areas of financial accounting, such as accounting for special-purpose entities. It may also be important to adjust for changes in accounting standards that occurred over this period. In financial accounting, certain assets and obligations on which tax is deferred may also have relevance, given useful available information.

The details of pension accounting are extremely complex, but some technical points could also be used to test the paper's hypothesis. There is somewhat faster amortization of actual asset returns in excess of the assumed return outside of a 10 percent corridor, which, if disclosed, could 
provide further information with which to test the hypothesis. Also, an additional liability is sometimes recognized on the balance sheet when the market value of pension assets is less than the accumulated benefit obligation. In 2001 and 2002 many firms will have been in this situation, and because this information is disclosed and available to the market, it may be relevant to the authors' hypothesis.

The discount rate used in calculating the obligation may also be quite relevant, and the Securities and Exchange Commission has indicated, both recently and in the past, some concern about misuse of these rates. In addition, some are confused by the different discount rates used for accounting purposes and funding calculations, and therefore I will review this topic here.

The ERISA discount rate used in funding is a formula rate, calculated as a moving average of the rate on thirty-year Treasury securities. It actually has no relation, either logical or empirical, with the rate stipulated by FAS 87, which is used by firms in their financial accounting.

The funding rules for pension plans provide for two funding accounts: a standard account and a backup account. The discount rate for the standard account is chosen by the actuary and usually reflects the expected return on plan assets. The backup account is for underfunded plans, and the discount rate there is a corridor of a weighted four-year moving average of the yield on the thirty-year Treasury bond, as mentioned above. This corridor itself has changed over time with changes in legislation. Figure 1 compares a time series of this discount rate for funding with the current yields on thirty-year Treasury bonds and on high-grade corporate bonds.

By contrast, the discount rate used in accounting is not formulaic. Instead FAS 87 explicitly delineates guidelines for setting appropriate rates. There is no connection to plan assets. Rates are to be based on current prices for settling the pension obligation in group annuity markets. These rates should vary depending on the duration of the liability. According to FAS 87, a plan "covering only retired employees would be expected to have significantly different discount rates from one covering a workforce of 30-year-olds. The disclosures required by this Statement regarding components of the benefit obligation will be more representationally faithful if individual discount rates applicable to various benefit deferral periods are selected."

4. Financial Accounting Standards Board (1985, paragraph 199). 
Figure 1. Legislated Maximum Discount Rate Used in Required Funding for DB Pension Plans and Selected Market Interest Rates, 1995-2003

Percent a year

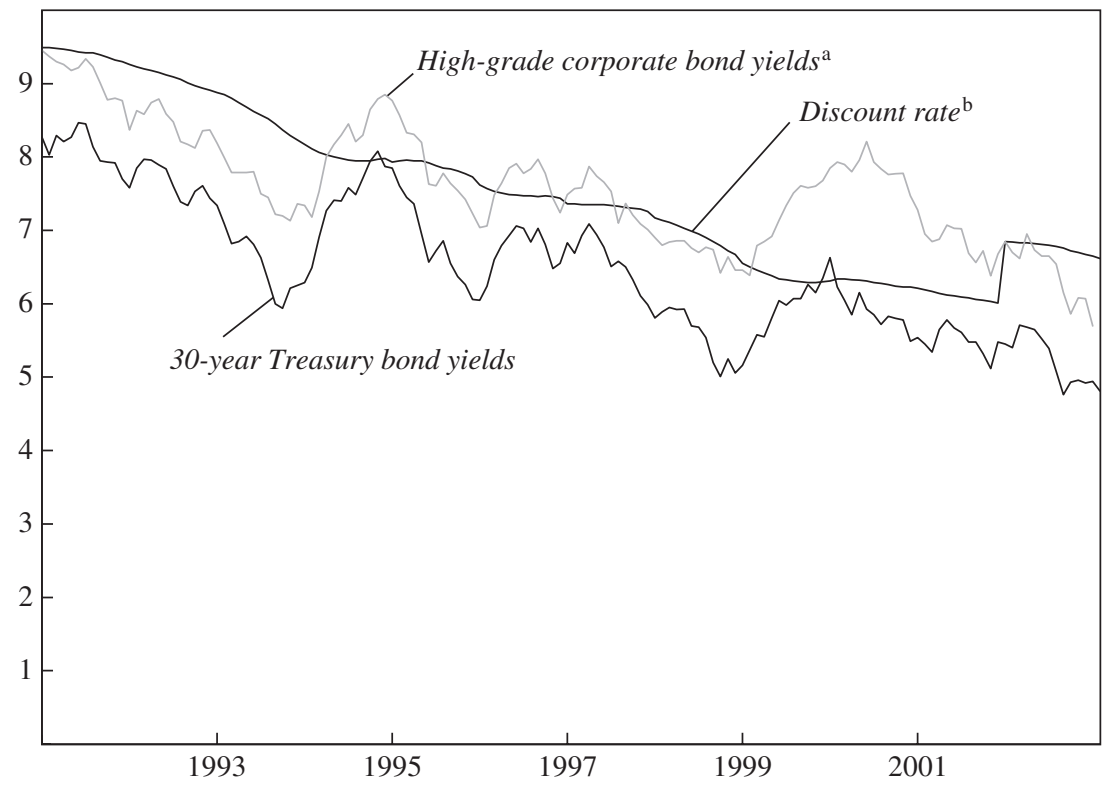

Sources: Salomon Brothers data and author's calculations.

a. Salomon Brothers yield on AAA/AA-rated corporate bonds.

b. Maximum rate of return that corporate DB plans are allowed to use in estimating the discounted value of plan benefits for funding purposes (current liability rate).

Salomon Brothers has implemented a pension discount curve consistent with FASB principles. Figure 2 shows examples for 1995, 1998, 2001, and 2002. FASB recommended use of a whole discount rate curve, not a single discount rate. The levels and the shape of the spot rate curve have clearly changed over time.

Whereas figure 2 shows what FAS 87 dictates should be done, figure 3 explains what has been done. The figure shows the distribution of actual discount rates used by S\&P 500 firms with DB plans. The distribution has tightened over time, perhaps in response to expressions of SEC concern. Figure 4 shows the average discount rate weighted by the projected benefit obligation from 1991 through 2001. The average in 2001, about $7 \frac{1}{4}$ percent, is considerably above the thirty-year Treasury bond rate and the current liability rate, somewhat above the rate derived from 
Figure 2. Salomon Brothers Pension Discount Rate Curve, Selected Years

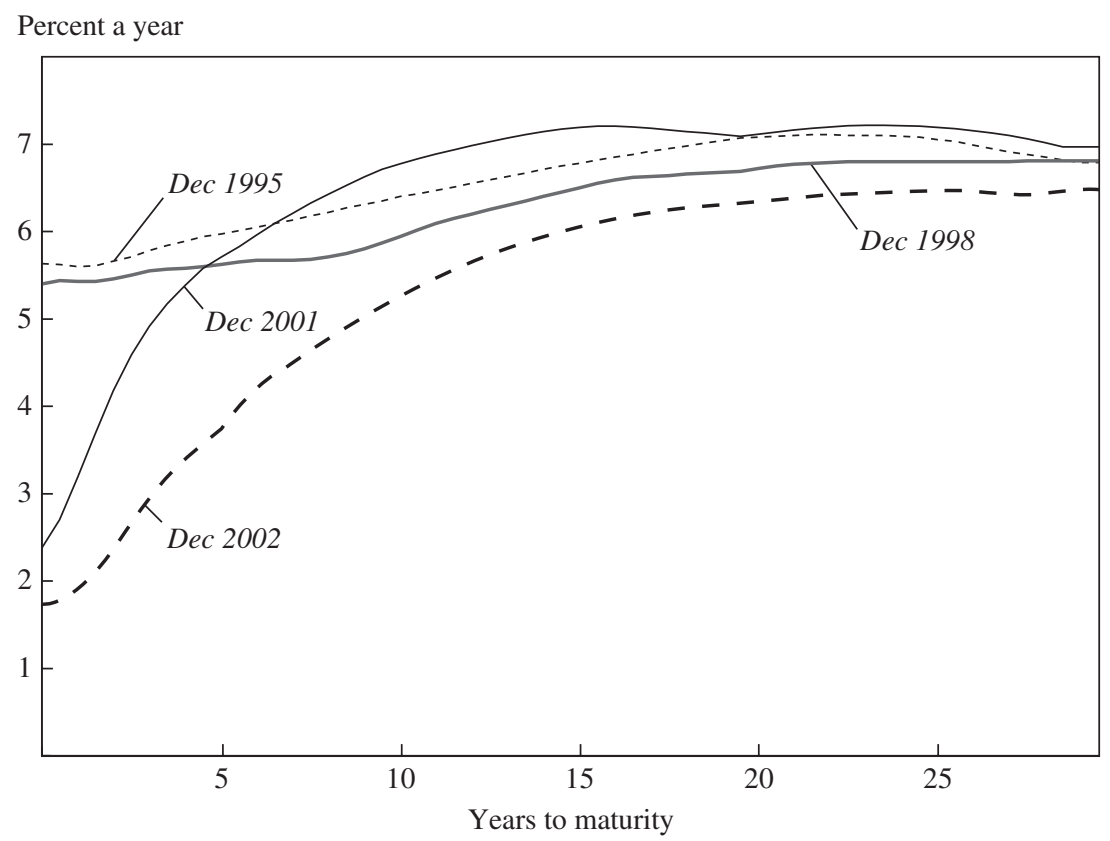

Sources: Salomon Brothers and Academy of Actuaries data.

the pension curve (particularly if the plan had older participants and many retirees), and about equal to the high-grade corporate bond rate, as shown in figure 1 .

The discount rate is very important in the measurement of the pension obligation and, therefore, of the net pension asset. The SEC, both in the past and more recently, has expressed some concern about the discount rates companies have used in calculating the obligations. Thus there may be measurement errors in net pension assets as well as in net pension earnings, to which the paper should give special attention.

As the paper states, there are indications of dissatisfaction with pension accounting as evidenced by S\&P's pro forma measures of core earnings and various Wall Street studies. In addition, pension accounting is complex, and some simplification may be desirable. The paper makes the very interesting point that having a DB plan may be positive for firm value, 
Figure 3. Distribution of Discount Rates Used in Financial Accounting for Corporate DB Pension Plans, 1991 and 2001 ${ }^{\mathrm{a}}$

1991

Number of plans

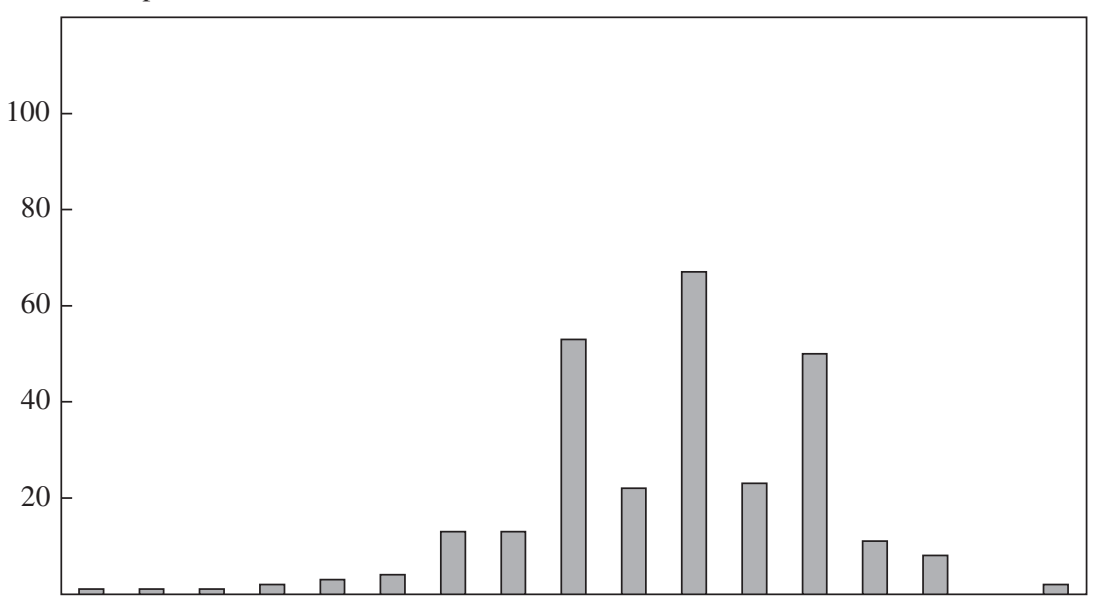

2001

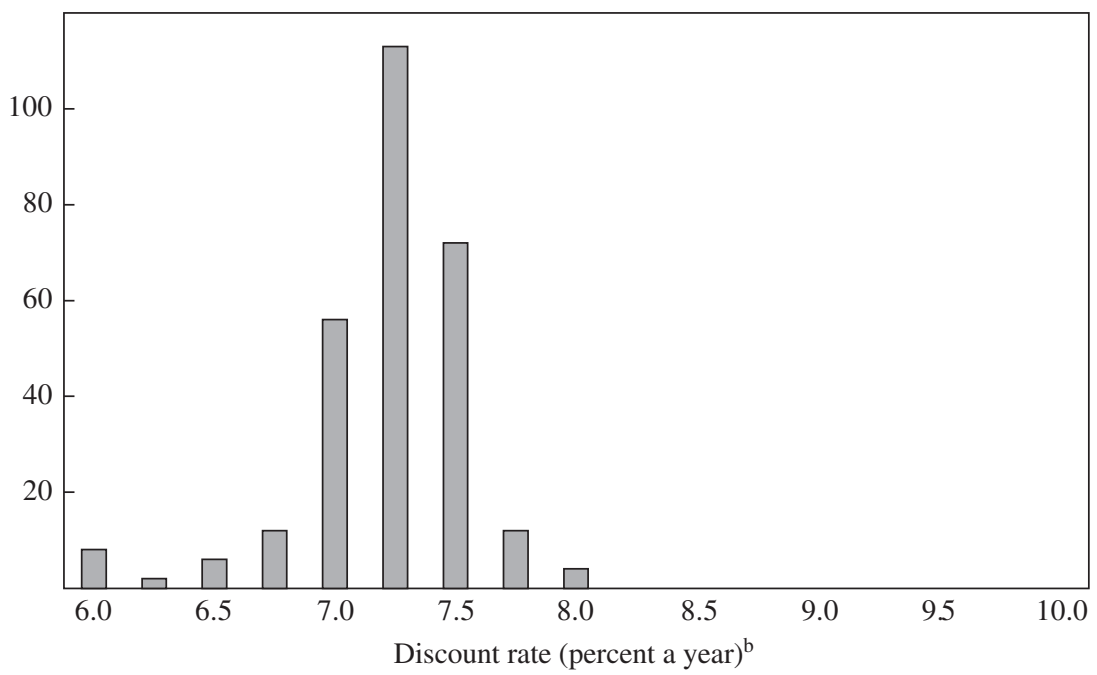

Source: Compustat data

a. S\&P 500 firms only.

b. Midpoint of range. 
Figure 4. Average Discount Rate Used in Financial Accounting for Corporate DB Pension Plans, 1991-2001 ${ }^{a}$

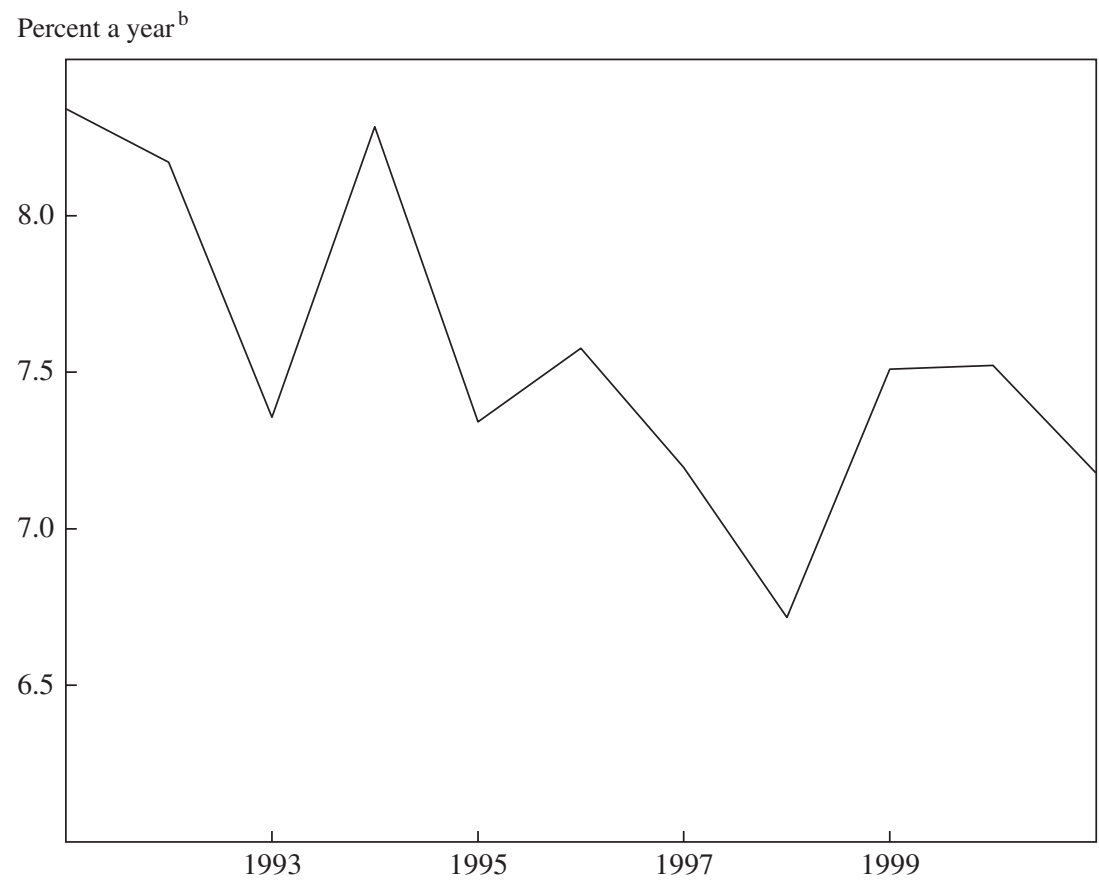

Source: Compustat data.

a. Weighted by firm pension benefit obligation.

which is a bad result, because it means that investors consider expectations of returns on assets without also considering the risk of those assets. This would indicate that stochastic demonstrations may have some place in financial accounting for pensions.

The paper's conclusions also have relevance to Social Security. Federal Reserve Chairman Alan Greenspan has suggested that the federal government adopt accrual accounting for Social Security and Medicare, and presumably this suggestion would also apply to other social insurance programs for which demographic trends are important. The experience with financial accounting for pensions and retiree health benefits is thus quite relevant. 
What can we learn from the experience with corporate financial accounting for pension plans? There is a tension between the accountants' desire for smoothing, on the one hand, and the need for timeliness and accuracy, on the other. There is also a tension between the need for simplicity and transparency, on the one hand, and the need to accommodate policy agendas and different economic situations, on the other. The present complexity in pension accounting has also arisen from competition between interest groups and their agendas. Clearly, accounting and disclosure both matter.

General discussion: Steven Durlauf criticized the dividend stock price model that the authors used in comparing pension valuation alternatives. He noted that the model has done poorly in numerous empirical investigations, stimulating the development of extensions such as nonseparable preferences and time-varying discount rates. This long history of empirical difficulties clouded the interpretation of the authors' results. For example, one of the measures of pension value would correlate better with the factors behind an unexplained market bubble, even though it did not represent a variable that investors focus on. Durlauf suggested that the authors provide checks on the robustness of their results to the chosen model specification. Steven Sharpe responded that the annual crosssectional regressions supported the dominance of pension earnings over net pension assets in all years except 1998, indicating that the basic results did not arise from the general stock price bubble.

Peter Orszag questioned the assumption that net pension assets should be valued somewhere between $(1-t)$ and 1 , regardless of how much the plan might be under- or overfunded. When a weak firm has a severely underfunded plan, the Pension Benefit Guarantee Corporation steps in, and a reversion tax applies to very high levels of overfunding. Orszag worried that using a common valuation of assets for all firms might bias the results, and he suggested limiting the analysis to firms whose net pension assets are within 5 or 10 percent of their pension benefit obligation. Julia Coronado agreed that the PBGC's insurance of pension assets would affect valuations. But she did not believe the empirical work was seriously affected, because the sample consisted overwhelmingly of profitable firms that were neither dramatically underfunded nor in a very weak operating condition. The sample thus largely excludes firms for which pension benefit obligations are not a correct measure of liability. 
Orszag also noted that pension benefit obligations are subject to considerable potential measurement error, both because of the somewhat arbitrary discount rate that firms use and because of many other assumptions that the plan's actuaries can make. Although it remains unclear how investors actually value these obligations, it is possible that they look through the actuaries' assumptions and come up with better valuations than those reported in the footnotes. While conceding this possibility, Sharpe noted that, in regressions that do not include pension earnings as a variable, pension assets and pension liabilities have coefficients of approximately the same absolute size when entered into the regression separately. 


\section{References}

Barth, Mary, William H. Beaver, and Wayne R. Landsman. 1992. "The Market Valuation Implications of Net Periodic Pension Cost Components." Journal of Accounting and Economics 15: 27-62.

1993. "A Structural Analysis of Pension Disclosures under SFAS 87 and Their Relation to Share Prices.” Financial Analysts' Journal 49(1): 18-26.

Black, Fischer. 1980. "The Tax Consequences of Long-Run Pension Policy." Financial Analysts' Journal 36 (July-August): 21-28.

Bodie, Zvi, and others. 1987. "Funding and Asset Allocation in Corporate Pension Plans: An Empirical Investigation." In Issues in Pension Economics, edited by Zvi Bodie, John B. Shoven, and David A. Wise. University of Chicago Press for National Bureau of Economic Research.

Brown, Stephen. 2002. "The Impact of Pension Assumptions on Firm Value." Unpublished paper. Emory University (April).

Bulow, Jeremy I., Randall Mørck, and Lawrence Summers. 1987. "How Does the Market Value Unfunded Pension Liabilities?” In Issues in Pension Economics, edited by Zvi Bodie, John B. Shoven, and David A. Wise. University of Chicago Press.

Ciesielski, Jack T. 2002. "Pondering Pensions 2001: The Face of Shmoo." Analyst's Accounting Observer 11(7-8, whole issue).

Daley, Lane Allen. 1984. "The Valuation of Reported Pension Measures for Firms Sponsoring Defined Benefit Plans.” Accounting Review 54(2): 177-98.

Davidson, Russell, and James G. MacKinnon. 1981. "Several Tests for Model Specification in the Presence of Alternative Hypotheses." Econometrica 49(3): 781-93.

Dechow, Patricia M., Amy P. Hutton, and Richard G. Sloan. 1999. “An Empirical Assessment of the Residual Income Valuation Model." Journal of Accounting and Economics 26: 1-34.

Dhaliwal, Dan S. 1986. "Measurement of Financial Leverage in the Presence of Unfunded Pension Obligations." Accounting Review 56(4): 651-62.

Feldstein, Martin S., and Randall Mørck. 1983. "Pension Funding Decisions, Interest Rate Assumptions, and Share Prices." In Financial Aspects of the United States Pension System, edited by Zvi Bodie and John B. Shoven. University of Chicago Press.

Feldstein, Martin, and Stephanie Seligman. 1981. "Pension Funding, Share Prices and National Savings." Journal of Finance 36(4): 801-24.

Feltham, Gerald A., and James A. Ohlson. 1995. "Valuation and Clean Surplus Accounting for Operating and Financial Activities." Contemporary Accounting Research 11(2): 689-732.

Financial Accounting Standards Board. 1985. Statement of Financial Accounting Standards No. 87: Employers' Accounting for Pensions. Stamford, Connecticut: Financial Accounting Standards Board. 
Godwin, Joseph H., Stephen R. Goldberg, and Jon E. Duchac. 1996. "An Empirical Analysis of Factors Associated with Changes in Pension-Plan Interest-Rate Assumptions." Journal of Accounting, Auditing and Finance 11(2): 305-22.

Gold, Jeremy. 2000. "Accounting/Actuarial Bias Enables Equity Investment by Defined Benefit Pension Plans." Pension Research Council Working Paper 2001-5. Wharton School, University of Pennsylvania.

Gopalakrishnan, V., and Timothy F. Sugrue. 1993. "An Empirical Investigation of Stock Market Valuation of Corporate Projected Pension Liabilities." Journal of Business Finance and Accounting 20(5): 711-23.

Gustman, Alan L., Olivia S. Mitchell, and Thomas L. Steinmeier. 1994. "The Role of Pensions in the Labor Market: A Survey of the Literature." Industrial and Labor Relations Review 47(3): 417-38.

Harris, Trevor S., and others. 2002. Pensions and the Cash Conundrum. New York: Morgan Stanley (July).

Head, S. J., and others. 2000. "Pension Fund Valuations and Market Values." British Actuarial Journal 6(1): 42-143.

McGill, Dan M., and others. 1996. Fundamentals of Private Pensions. University of Pennsylvania Press.

Mittelstaedt, Fred H., and Mark J. Warshawsky. 1993. "The Impact of Liabilities for Retiree Health Benefits on Share Prices." Journal of Risk and Insurance 60(1): 13-35.

Munnell, Alicia H., with the assistance of Nicole Ernsberger. 1987. "Pension Contributions and the Stock Market." New England Economic Review (November-December): 3-14.

Ohlson, James A. 1995. "Earnings, Book Values and Dividends in Equity Valuation." Contemporary Accounting Research 11(2): 661-87.

Sharpe, Steven A. 2002. "How Does the Market Interpret Analysts' Long-term Growth Forecasts?" Finance and Economics Discussion Series 2002-07. Washington: Board of Governors of the Federal Reserve System (September).

Sharpe, William F. 1976. "Corporate Pension Funding Policy." Journal of Financial Economics 3(3): 183-93.

Tepper, Irwin. 1981. "Taxation and Corporate Pension Policy." Journal of Finance 36(1): 1-13.

Zion, David, and Bill Carcache. 2002. The Magic of Pension Accounting. New York: Credit Suisse First Boston (September). 
